
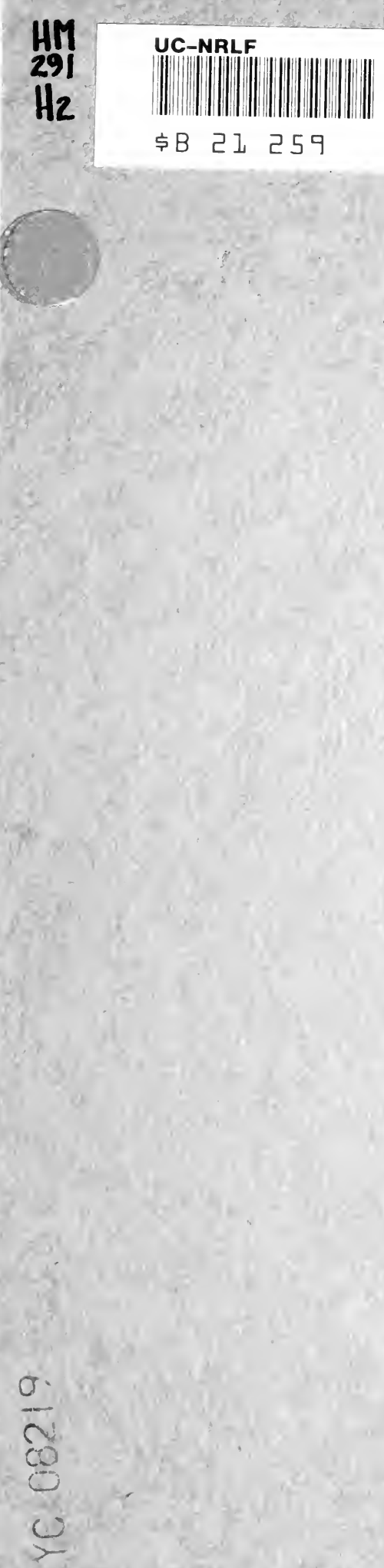


\section{Digitized by the Internet Archive in 2007 with funding from Microsoft Corporation}




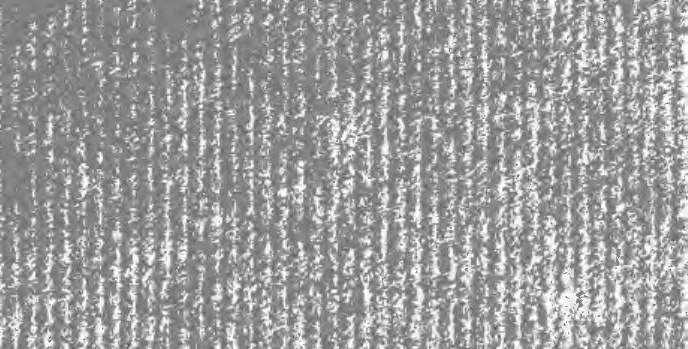

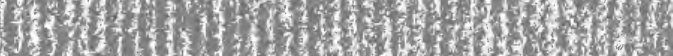

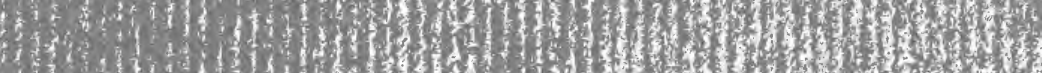

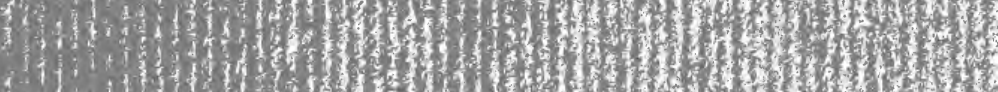

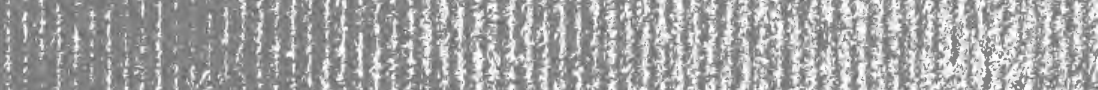

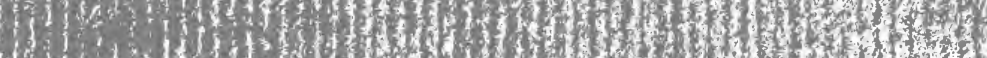

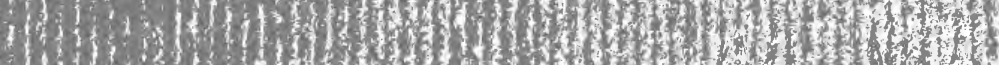
H) H.7.

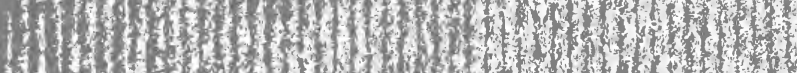

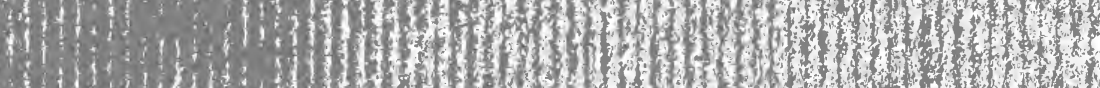

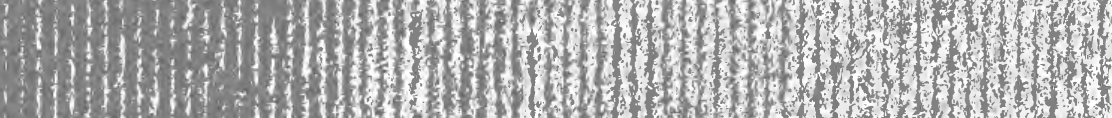

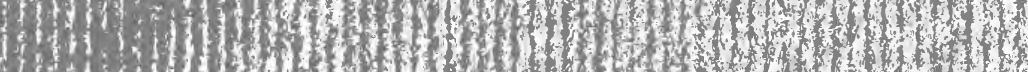

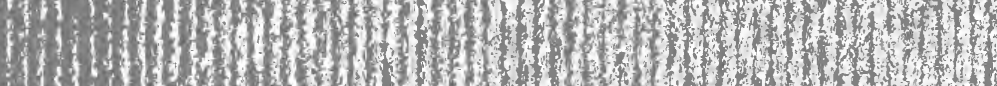

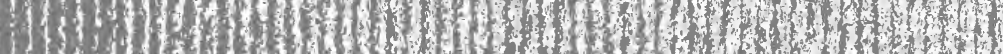

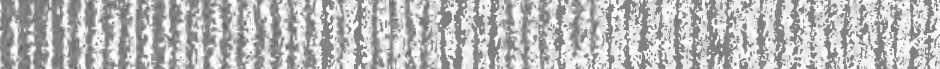

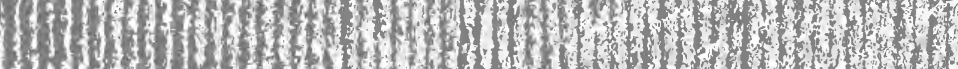

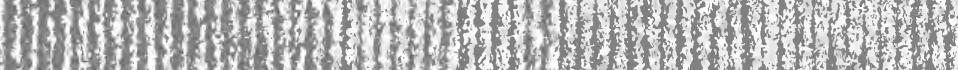

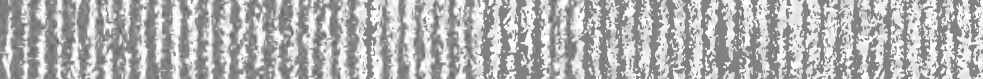

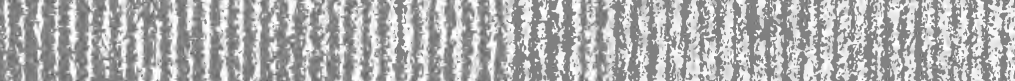

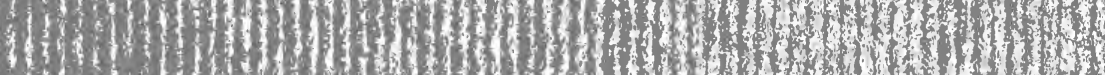

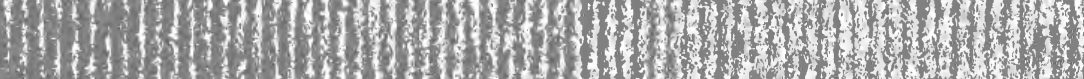

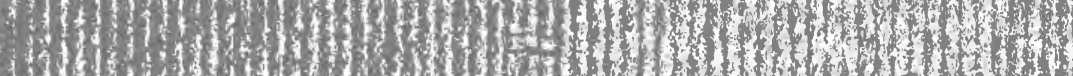

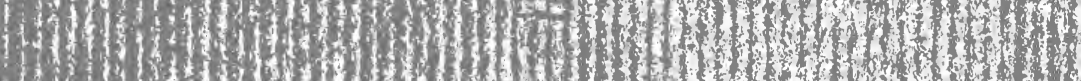

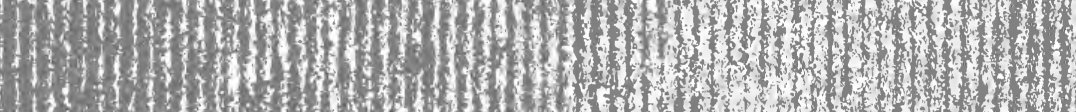

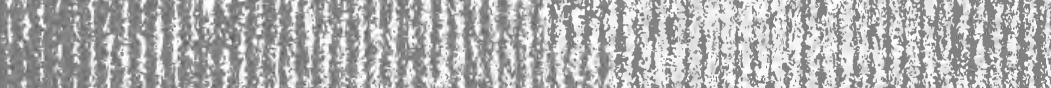

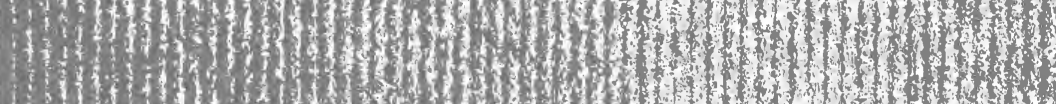

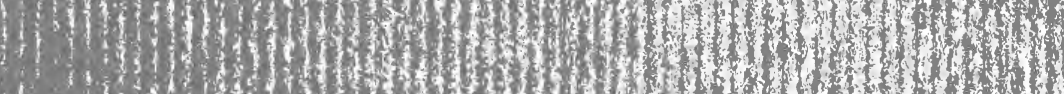

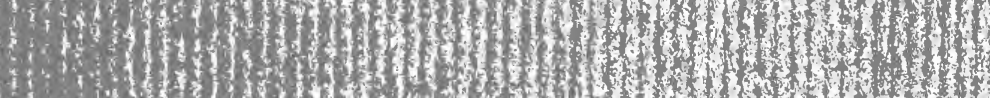

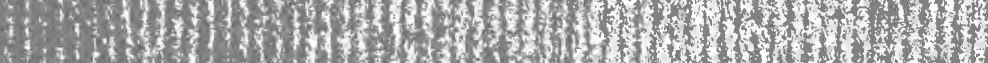

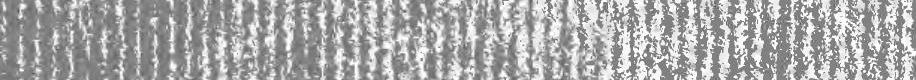

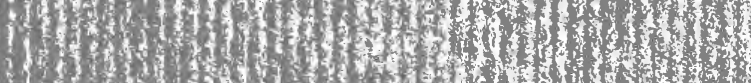

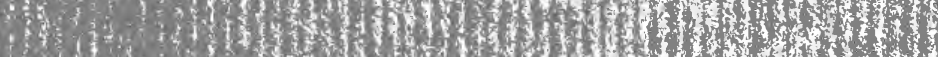




\section{The Psychology of the Club; A \\ Study in Social Psychology}

BY

LOUIS D. HARTSON

A DISSERTATION SUBMITTED TO THE FACULTY OF CLARK UNIVERSITY, WORCESTER, MASS., IN PARTIAL FULPILMENT OF THE REQUIREMENTS FOR THE DEGREE OF DOCTOR OF PHILOSOPHY, AND ACCEPTED ON THE RECOMMENDATION OF G. STANLEY HALL

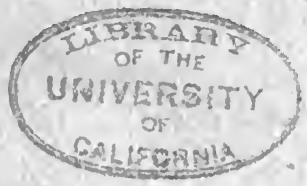

Reprinted from the Pedagogical Shminary September, 1911, Vol. XVIII, pp. 353-414 



\title{
The Psychology of the Club; A Study in Social Psychology
}

\author{
BY \\ LOUIS D. HARTSON
}

A Dissertation SUBMItTed to THE FACULTy OF CLARK UNIVERSITY, WORCESTER, MASS., IN PARTIAL FULFILMENT OF 'THE REQUIREMENTS FOR THE DEGREE OF DOCTOR OF PHILOSOPHY, AND ACCEPTED ON THE RECOMMENDATION OF G. STANLEY HALL

Reprinted from the Pedagogical Seminary September, 1911, Vol. XVIII, pp. 353-411 


$$
\mathrm{H}^{\mathrm{M}^{2}}
$$

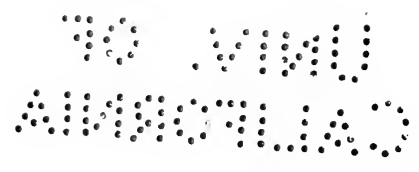




\title{
THE PSYCHOLOGY OF THE CLUB; A STUDY IN SOCIAL PSYCHOLOGY'
}

\author{
By LouIS D. HARTSON
}

\section{INTRODUCTION}

The Spectator says that there is nothing, as far as he can see, that any human being can desire to do, to think, or to work for, that has not a society all ready for him or her to enter. The path of life is beset with membership from the cradle to the grave $(74)$. The kindergarten has its alumni association, invalids have their Shut-In Society, the poor organize, the rich organize, everybody belongs to some sort of a club. At a recent murder in one of our large cities the jury, though it had shown itself unable to agree on a verdict, agreed at once, as soon as discharged, to organize as a permanent society, pay dues, and have an annual dinner. The Spectator expects soon to see an announcement of the formation of the Daughters of Ellis Island with Wilhelm der Grosse Chapters or Lusitania Leagues.

For the purpose of studying this phenomenon of the social structure data have been gathered ostensibly in all the most prominent forms of its manifestation. Obviously those societies formed by one group of people for another group, such as societies formed by adults for children, are of less importance for psychological interpretation than are societies formed by groups for their own membership. We present the data therefore only of this latter type of society. In order to have a generic term which will include all such societies, and because the word society has a double meaning, we employ the term club. The object of this paper is to make a psychological interpretation of the club as a social institution. The first section presents the facts regarding the existence

'In this all too unsatisfactory manner the writer desires to acknowledge the helpful assistance he has received in the preparation of this thesis. Primarily in point of time should be mentioned the inspiration received from Dean Thomas M. Balliet, of New York University, and the two years training in boys' club work under Miss C. I. MacColl, of Christodora House, New York City. For material used in this thesis the writer is indebted to Prof. Will S. Monroe, of Montclair, N. J., and Miss Clare Lyon, of Lidgerwood, N. Dak. In the interpretation of the data a debt has been incurred to all of the Clark University faculty, and particularly to Dr. T. L. Smith who is truly the research assistant of all the students. 


\section{4

of clubs in this country important for this intrepretation. Beginning with the field of children's group activities the course of development is observed through the gang into the club, which is followed in its evolution to the mature form found among adults. Having thus before us the facts our problem consists in interpreting them on the basis of what is known of functional psychology.

\section{Section I. Presentation of the Data}

\section{Chap. I. Group and Gang Life in Children}

The club viewed genetically has a gradual growth. It does not spring up as a mature institution at any one definite chronological period in the life of a group of individuals. Its beginning is to be traced back into the group activities of childhood. Gulick says that the first appearance of group games is at about 7 , in which games the centre of interest is one's self in relation to others (34, p. 39). The games played are the simple ball games, such as one old cat, running games like tag, prisoner's base, hide and seek and black man, and the marble games. There are throwing games like duck on the rock, the highly individualistic game of stunts or follow the leader, in which one boy performs some difficult or daring feat and the game consists in having the other boys one by one, do the same thing in the same way. Other games of this period are leap frog, mumble the peg, etc. This is the time when predatory activities gain prominence as do the closely allied activities of hunting, fishing, swimming, skating, snowballing and the so-called savage activities. More highly organized group games appear at approximately the age of I2, according to Gulick. Teamwork is the keynote now. The more common of these games are baseball, basketball, cricket and hockey (34).

Zach. McGhee found that group games began earlier than 12 (50). He gathered returns from about 10,000 children in South Carolina between the ages of 6 and 18 , which designated the 5 favorite games of their choice from a long list submitted to them. Baseball was found to be one of the favorite games by $57 \%$ of the boys at the age of 6 , and football by $43 \%$. Even though these games be poorly organized among boys of this age it is evident that they are very popular. In later years they become even more popular. The curves for baseball show an upshoot at II. From being the choice of $57 \%$ at 6 years it is preferred by $72 \%$ of the boys of $I I$ and continues at that level till 18, the age limit of the study. Football shows a steady growth in popularity from 6 to 16 . Considerable difference is evident between the sexes as to the degree of organization and co-operation in the games preferred. Having grouped the games which require co-operation, McGhee found that this curve was low for girls throughout the whole period from 6 to 18 . His returns support the thesis that games requiring organization and rules do not appeal to girls. Of the 12 games receiving the highest number of votes 5 are totally lacking in co-operation, while most of 
the others have but little organization. Croquet, the only organized game that is anywhere high on the girls' list is very low until the age of 12. On the other hand unorganized games are abnormally high until that age. Girls' favorite plays for the entire period from 6 to 18 rank as follows: dolls have the first place, chosen by $28.7 \%$ of the girls; jump rope, $21.6 \%$; between 1o and $22 \%$ are ranked authors, crokinole, open gates, parchesi, hide and seek, drop handkerchief and dancing.

Scott characterizes the period from 9 to 12 as one of increased activity in which the games are co-operative but poorly organized (66). His data are gathered from returns to a questionnaire sent out in Springfield, Mass. In 90 cases the returns came from adults; in the other 490 they were from boys of 10 to 18 years. Boys not belonging to a group were asked whether they had a few chums. The returns showed that $68.5 \%$ belonged to a group and that $18 \%$ of the others had chums. Scott considers a group containing less than 5 as too small to constitute a gang; if 4 boys associate together he considers them as chums. Groups as large as 9 were found among the younger boys. With increasing age the size of the group decreased. He declares the period from 12 to 14 to be that of the closely organized group. Two-thirds of the boys he questioned said that their gangs had secrets, though sometimes this was nothing more than a certain whistle or call. One half of them had some sort of an initiation.

The period from 6 to 10 is the time when the formation of chumship is most frequent, according to Bonser (II). In studying 756 boys and 1,279 girls in Illinois he found that the tendency toward chumming becomes very strong in girls as early as 5 years and reaches its height at 6 , when $15 \%$ of such friendships were formed. Among boys this tendency develops a little later and reaches its minimum at ro. Bonser treats only the relationships between two individuals, on the basis that three is a crowd. Of the 2,000 , only 40 state that they never had chums. His returns indicate that after puberty the formation of this type of relationship falls off very rapidly. Nearly half of the answers were from pupils of the latter half of the high school course. Between 13 and 17 the curve of frequency of forming chumships falls from 8 to less than $1 \%$ of the cases. Chums of early years continue to be such through the later years. Chums are reported as being of the same age. Differences in the ages of two chums exceed 2 years in only $2 \%$ of the cases for boys and $\mathrm{I} \%$ for girls. Bonser says that if older associates are chosen they are not made chums or cronies of the confidential sort (II, p. 224). Those reporting dispositions opposite to or different from their chums are $22.2 \%$ of the girls and $24.2 \%$ of the boys. The remaining number replied that they were the same or similar. Statements were made by 18 boys and 26 girls that they never had chums. In most of these cases, as shown by the other answers, there appeared an over developed self-consciousness which restricted naturalness. Of the 756 boys and 1,179 girls reporting but $12.4 \%$ of the former and $16.6 \%$ of the latter state that the friendship with their chums were broken. Of these, 34 boys and 62 girls give as their reason the fact that they moved away from the neighborhood in which the chum lived. Quarrels were stated as being the cause by 12 boys and 14 girls.

A study of the 146 boys in the Lyman School, Westborough, Mass., (a reform school) by Puffer (6r) showed that 128 of them had been members of gangs. These boys ranged from II to 16 years. The average age of the youngest boys in the gangs studied was 12.1 years, that of the oldest was 16.25 years. The youngest boy in the gang was 7 ; the oldest was 19 . Only 3 of these gangs existed in country towns and only 4 from places less than 10,000 in population. This only shows, Puffer says, that boys from country towns are not sent to a reform school. These 128 boys belonged to 66 different gangs. Of these, 44 had I leader, 8 had 2 leaders, and a few had more than 2. The average size of the gang was 10. In 24 cases the leader informally took upon himself that office; in 4 cases the boy was 
informally given the leadership, and in 4 more cases he was elected by ballot. In most cases the boys did not know how the gang started, for only 17 could give any report. Of these, 6 said that the gang was started by the leader; 11 stated that they had been in the gang 5 years or more. Strangers were treated with little sympathy or were maltreated. Loyalty to the group was found the dominant motif in the rules. Of the 51 rules reported by the various gangs, 18 were against "squeeling," 8 against lying to one of the gang, and 8 required standing by one another in trouble. Out of the 54 records there were only 7 gangs which did not meet every day; of these, 3 met 3 times a week, 2 twice a week, and 1 once a week. In the records of 63 gangs all but 4 had regular meeting places. The gangs have a proprietary feeling for the neighborhood of their meeting place. Only 8 of these gangs were exclusive in membership, though they generally had a definite rule to entrance to regulate. These regulations show that they did not have to recruit members; that the new boys wanted to get into the gang. Out of 48 gangs only I I report any form of initiation. The chief occupation of these gangs was some form of physical activity. Under this title may be grouped co-operative and nonco-operative games, fighting, predatory and migratory activities and the other outdoor occupations designated as savage. The occupations which did not find their chief element in physical activity include theatre-going, mentioned by 38 gangs, card-playing by 25 , gambling by 12 , smoking by 30 and drinking by 9 . The attendance at theatres was not by gangs but by twos and threes. However the necessary money was obtained by gang activity. Of the physical activities, co-operative games were the most popular. Out of 66 gangs 53 have records of games requiring co-operation, such as baseball, football, hockey, basketball and cricket; 49 of the gangs spent part of their time hunting, fishing, berrying, building boats, shanties and dugouts, and camping. Predatory activities in the form of stealing were reported by 43 gangs. Fighting between gangs both of the innocent snowball variety and with fists, stones and clubs, was reported by 22 different gangs. Activities which resulted in plaguing people, such as tick-tacking on the windows, ringing doorbells, calling names at Chinamen, Jews, Italians and policemen were mentioned by 45 gangs.

Browne (12) made a study of 'gang instinct in boys' which corresponds with the data Puffer gathered, though the sources were rather different. Browne went through books on boy life by Aldrich (5), Howells (4r), Hutton (42) and Warner (85), the studies of Sheldon (67), Gulick (34), and Culin $20)$, the reminiscences of 50 students at the International Y. M. C. A. Training School, newspaper stories and the answers received from a number of boys on the street. Of the 5o students, 25 had been members of gangs. In 20 cases the ages of the members of the gangs was given. The extremes were 7 and 18 . Within the gang the disparity of ages ranged between 2 and I y years (the latter exception being in a town gang of 75 boys). The medium disparity in ages was 4.5 years.

Stewart Culin (20), writing in 1891 , gives the names of 50 different gangs in Philadelphia which he obtained by personal inquiry among the boys along the Schuylkill River front. He gives no other details except to say that they had their laws and customs, their feuds and compacts. The names would suggest that the boys were of tough character. Similar conditions have been reported by social workers in other cities. Jacob Riis wrote in 1890: "The gang is an institution in New York. . . Every corner has its gang. - The gangs belt the city like a huge chain from the Battery to Harlem. . - They have their 'club rooms' where they meet, generally in a tenement, sometimes under a pier or a dump, to carouse, play cards and plan their raids. . The fiction of a social 'club', which most of the gangs keep up, helps them to a pretext for blackmailing the politicians and the storekeepers in their bailiwick at the annual sessions of their picnic or ball" (64, p. 217-230). Speaking of Boston, Robert A. Woods wrote in 1898: "Almost every boy in the tenement-house quarters 
of the district is a member of a gang. The boy who does not belong to one is not only the exception, but the very rare exception. There are certain characteristics in the make-up and life of all gangs. To begin with, every gang has a 'corner' where its members meet. This 'hang out,' as it is sometimes called, may be in the centre of the block, but still the gang speak of it as the 'corner'. The size of the gang varies; it may number five or forty. As a rule, all the boys composing it come from the immediate vicinity of the corner. Every gang has one or two leaders; and of course its character depends very much upon the leaders, for as one of the boys expressed it the leader says " Come" ' and the push move' . . Nightly after supper the boys drift to their corner, not by appointment, but naturally. Then ensue idle talk, 'jawing matches,' as one boy expressed it, rough jokes, and horse-play. . . I am referring now more particularly to boys over fourteen years old. . . About thirty young men belonging to one of the gangs I know, meet every Sunday afternoon at their corner. Of this number, fully half are fellows who live in the highlands, at the edge of Roxbury. I know a boy in High School-he will graduate next yearwho moved to Dorchester, but comes regularly to the old corner on Sunday afternoon. No new friends can supplant the gang. . . It is interesting to know what becomes of these various gangs when the boys get to be seventeen or eighteen years old. The more respectable gangs, as a rule, club together and hire a room. The more vicious prefer to use what little money they have in carousing" (87, p. I14-118). From her Chicago experience Jane Addams says, in the same words Mr. Woods uses: "the boy in the tenement house region who does not belong to the gang is not only the exception, but a very rare exception"' ( $1, p .176)$.

\section{Chap. II. The Boys' and Girls' Club}

Henry D. Sheldon made a comprehensive study of the institutional activities of American children (67). According to the data gathered from 2,508 papers of value written as a classroom exercise, received from children of the ages 8 to 17 , from 5 localities, East and West, rural and metropolitan, $68 \%$ were or had been members of clubs. Many of these were of adult formation, leaving $\mathrm{r}, \mathrm{I} 66$ purely spontaneous children's organizations. An attempt was made to divide the societies into groups on the basis of their activities, with a separate group for those having secret elements. The figures are presented in a chart. For the purpose of making a comparative study these figures have been worked over and are shown in the accompanying table. For each age from 8 to 17 are shown the number of papers collected, the number of spontaneously formed societies, the number of societies described in the papers which were formed by adults for children, the percentage of those belonging to spontaneous and adult formed societies. In order to compare the activities at the different ages their relative importance among spontaneously formed clubs has been worked out in percentages. The groups Sheldon made are entitled: secret, predatory, athletic, social, industrial, philanthropic, and in one group literary, art, and musical societies. 


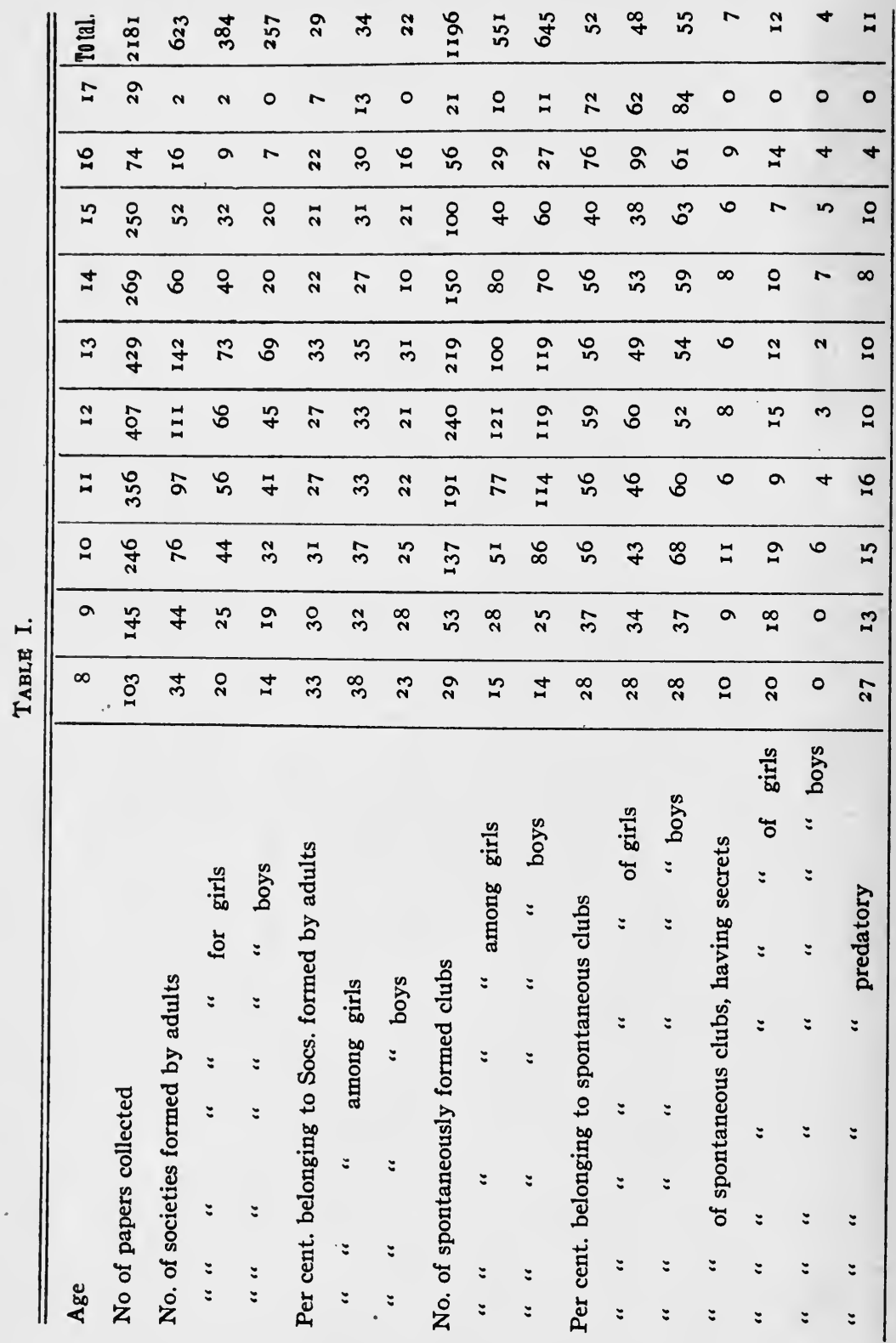




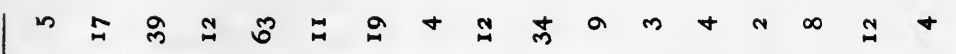
- 0 4

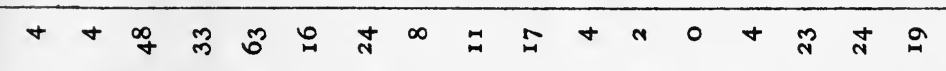

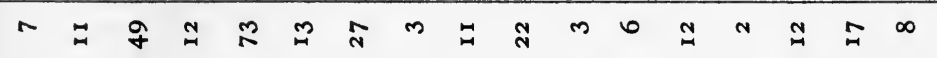

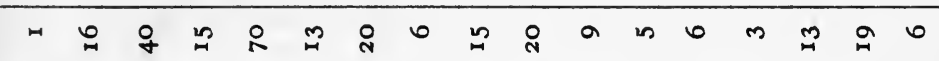

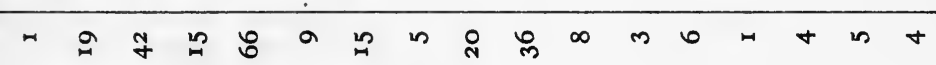

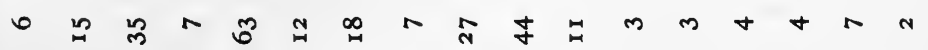

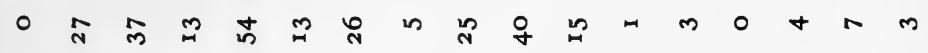
0 a $\stackrel{a}{\infty}_{\infty}$.

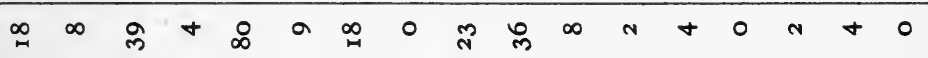

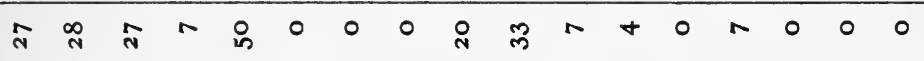

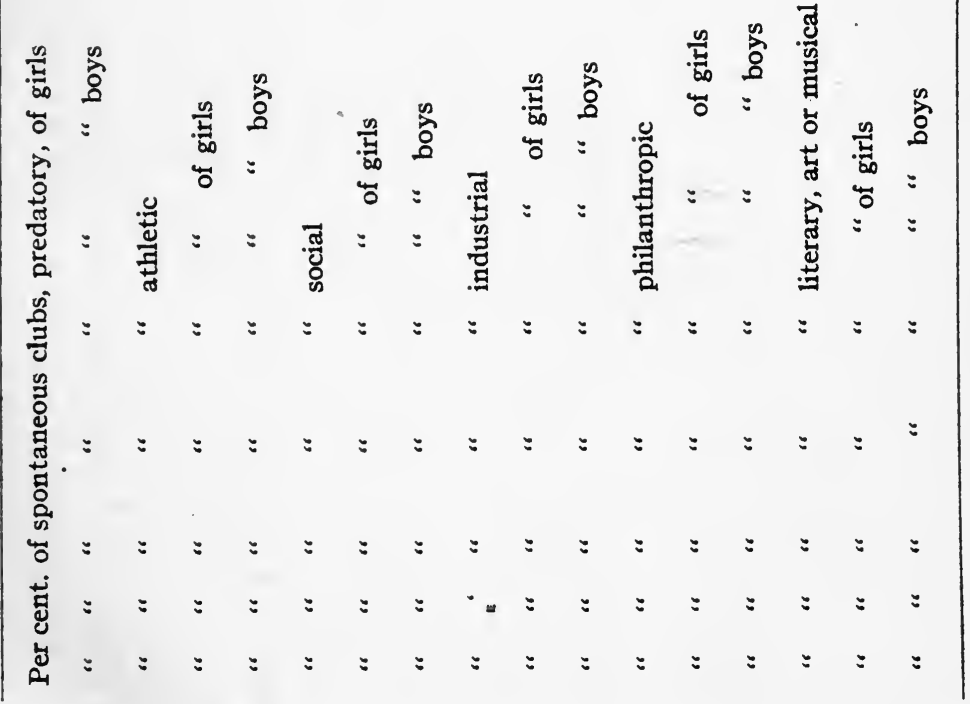


At the age of 8 , with which the investigation began, the percentage of those answering who belonged to spontaneously formed clubs was 28 . As the returns received were class room exercises given to all the pupils in the grades investigated, 2,906 in number, these figures may be taken as representing approximately the proportion of such school children belonging to clubs. Of this large number only 224 did not write; of the returns received 398 were defective in some details though they all described clubs. The height of the curve of membership is reached at 12 when over half of the pupils belonged to clubs. Comparing girls and boys the age of 8 shows both sexes at a level, 28 per cent. 'The girls' curve reaches its apex of 60 at 12 years, the boys' curve rises to 68 at io and then diminishes. In all cases the figures for the ages of 16 and 17 are so few as to invalidate them. Of the girls $48 \%$ belonged to clubs of their own formation; for the boys the figure is $55 \%$. Certainly Puffer (6I, p. 178) and Forbush (27, p. 314; 26, p. 44) are unintentionally misinterpreting the facts when they say that Sheldon's figures show that only $7 \%$ of the clubs were formed before IO and that I I, I 2 and I 3 are the ages when the largest number of clubs were formed. Sheldon's figures furnish no direct information on the question as to when the clubs were formed nor their duration, though they suggest that they were formed much earlier than Forbush and Puffer say. The years when they were most prevalent are from Io to 14.

Despite the instructions that none but spontaneously formed clubs be described 623 clubs formed by adults for children were written up. The curve of relation between the number of these and the total number of papers collected shows a percentage at 8 years of 33 . Except for a rise again to 33 at 13 there is a general decline with age. Girls outnumber boys in the ratio of $34: 22$ in these societies.

A consideration of the activities of these clubs shows that secret organizations which constitute $7 \%$ of the clubs are slightly more popular in the earlier years, and that they are predominantly found among girls. These were, Sheldon says, mostly social or 'good time' clubs, though other types of clubs also had secret features. A better classification would have counted these also under the separate headings. The curve for predatory activities begins at $17 \%$ and gradually diminishes. With 8 and 9 year old girls it is as prominent as with boys; after that it drops rapidly. The curve for boys continues to be high until 15 . The term predatory however is given a very loose meaning. A better term for what is meant would be unorganized play as contrasted with athletics, $i$. $e$., the plays carried on without rules and being unruly. For organized games or athletics the curve rises from $27 \%$ at 8 , to 48 at io, 
drops to 35 , at 12 , and then rises to 49 , at 15 . This is dominantly the boy's type. 'Though it rises to 15 from 7 with girls, it continues to be but a minority choice throughout. The girls' popular choice consists of those activities which Sheldon groups together as industrial occupations, sewing, giving shows, playing store and collecting. This curve rises from 33 to 44 , then drops to ro. With boys it starts at $7 \%$, reaches 15 at I I years, and then drops. Philanthropic organizations, which constitute $3 \%$ of the spontaneous clubs, consist in his study of 2 types, those whose chief object is to help other people and those formed for mutual help against such vices as swearing, using slang, smoking and the like. The group of social clubs constitutes $11 \%$ of the whole. This is dominantly a girl's club, with whom it varies from 15 to $27 \%$ after its appearance at 9 years. Only the philanthropic clubs have a lower standing in relative importance with boys, social clubs being on a par with secret clubs, literary, art and musical organizations. This last group is the latest to appear. At I I years it reaches $4 \%$ and until 16 never goes higher than $13 \%$. Boys and girls do not organize together.

In addition to the data from children Sheldon collected reminiscences from 453 adults in response to a questionnaire. These he does not tabulate but summarizes and generalizes.

The period before ro years he characterizes as the stage of imitation. At this time the play mimics the occupations of adults whom they see, hear or read about. The second period, from ro to 14 , he calls the period of invention and the following of instinct. We shall defer interpretation till the second section of the paper. It must be said in passing, however, that the cases cited as illustrations of this new element of invention and instinct include a case of a Jesse James gang, a typical gang with a club house and an Indian club. The cases he cites do not support the thesis of the appearance of invention at this age.

The quotation above from Mr. Woods ended with the statement that the more respectable gangs form clubs. His description of them particularly emphasizes their rôle in politics. There are 8 of these young men's clubs in his district of Boston. In New York they are much more numerous and similar conditions exist in other cities. One of the chief undertakings of these 'social pleasure' clubs, as they are generally called, is the management of an annual ball held in one of the public dance halls. During the winter months in Tammany Hall, Arlington Hall, Clinton Hall and the hundreds of other dance halls in New York several 'Full Dress and Civic,' Mask Balls, or 'Barn Dances' per week are held by these social clubs, so numerous are they. One club 
whose meetings and dances the writer has attended held two 'annual balls' the same year. Picnics are held in the summer. Most of the members of these are wage earners and unmarried. They hire a parlor floor, sometimes also a basement where they hold dances for members and their friends only. Nearly all of them have back rooms where gambling may be carried on undisturbed by the police. Here the unemployed members may find a loafing place. In the evening the members gather informally with their tobacco and beer for a general good time, singing, clog-dancing, cards and story-telling.

It is but a step from this the 'social' club to the 'benevolent' society, the additional element being that each members pays weekly dues or 'benefits' to sick members. These are not to be confused with the great fraternal organizations existing throughout the country, but a certain relationship is evident. These clubs formed by boys in their teens grow in to the adult organizations to be treated in the following chapter. To show the similarity reference may be made here to the clubs of thieves and pickpockets which are started by adolescents. Very frequently the police trace stolen goods to the club rooms of a gang of thieves. Pickpockets also have organizations of this character. A short time ago a smart fellow caught one of this gang picking his pocket and held the man's hand in his own pocket. He was about to turn the man over to the police with the proof, whereupon the pickpocket begged for mercy and promised that our friend should never be picked again. Moreover he promised that if at any time $\mathrm{Mr}$. X should need any assistance he would get it by visiting the club, and when released the pickpocket invited his intended victim down to the club rooms on a certain night. At the appointed time our friend called on the pickpockets and received a royal welcome.

As illustrating the wide spread character of these social clubs the experience of the evening recreation centres in the New York Public Schools is enlightening. In the year 1899 the public schools were opened in the evening, with paid instructors in charge, for general recreative purposes. The last report of the city superintendent $(5 \mathrm{I})$ gives statistics of 744 clubs which have come into the schools from outside because here is provided a warm and lighted meeting place. The settlement houses have the same experience constantly. To some extent no doubt the formation of clubs out of unorganized gangs of the street corners has been stimulated by this provision of attractive meeting places and the additional incentives of gymnasium, baths and other advantages, especially the privilege of special rates at summer camps, but this stimulation is in itself inadequate to explain the existence of 
the spontaneously formed clubs, as some social workers have maintained.

The athletic club is an institution of great significance among the boys of the cities. Such organizations as the Irish-American, the Crescent and others will be treated under the heading of adult clubs. Among boys and young men small athletic clubs flourish particularly abundantly during the summer, as the advertising columns of the evening papers well show. A single edition of the Evening Journal will contain advertisments for ball games by scores of teams. A typical notice is the following: "The Alco A. C. (uniformed) desires to schedule games with 15 yr. teams for Sunday afternoons in July, to be played at Pelham Bay Park." Several of the papers conduct in this way an extensive engagement bureau. The recreation centres and playgrounds furnish the opportunity for competitive contests in basketball, gymnasium and track events as well as baseball.

Because of the fact that no data except that furnished by Sheldon has been published regarding girls' spontaneously formed clubs, the writer has made a special study of this type of organization. Through Prof. W. S. Monroe reminiscences were obtained from I 89 girls in the State Normal School at Montclair, N. J. Prof. Monroe asked the members of his psychology classes to write an account of the clubs they had been instrumental in forming, the organizations which were spontaneously formed by the girls themselves and independent of adult interference. They were asked to tell the number of members and their age, the duration and the ostensible purpose of the clubs, to state the basis of membership, and whether or not there were any secret characteristics. Of the girls in these classes only 17 , or $9 \%$ of the whole number, had not been members of some spontaneously formed club. Some had belonged to more than $I$, the 172 girls reporting and describing 26r clubs.

The curve of age for the formation of clubs covers the span from the fifth to the eighteenth years. The one case of a 5 year old girl was exceptional; they wanted to exclude all under 7 but her sister's influence got her in. Of the 236 cases where age was stated the medium was 12 , the average I I.9. The curve shows that the period when the formation of clubs was most frequent was 9 to 14 . In 6 cases the age was given as being 8 to 9 . If we count these as being under 9 we have 32 cases of clubs formed before 9 , or $13 \%$ of the total. Only 37 , or $16 \%$, were formed after the age of 14 . Of the total number 218 report the duration, or length of time of existence. This varies from 1 hour to 5 years, and in 7 cases the clubs 


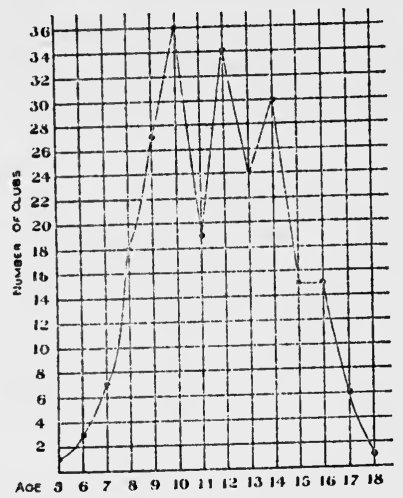

Age of Girls when

they formed Clubs.

still exist. The average duration is 9.7 months. 209 report membership. This varies from 3 to 50 . The average is 8.r.

The ostensible purpose of these clubs was declared to be dominantly social or for a good time in I I cases; in 3 others this is a subordinate motive. Sewing is the chief motive in $\mathbf{I}$ clubs, and a subordinate motive in $3 \mathrm{I}$ others. $2 \mathrm{I}$ clubs are dramatic, 4 subordinately so; 13 are declared to be dominantly philanthropic and 19 have this as an incidental motive; I4 are dominantly literary, 4 subordinately literary; secrecy is the sole motive in 18 cases and in 6 cases it is a subordinate motive; 4 are for spite; ro clubs are athletic; 3 are card clubs; 3 have a religious motive; in 2 cases each the chief purpose is exploring, music, languages, and for the protection of animals; in I case each, clubs were formed for the study of birds, of algebra, history, large cities, and of civics, and I was a postal club, I an Indian club, I for self-improvement; 2 had as a subordinate purpose the elimination of slang among the members. Adding the dominant and subordinant purpose and figuring the percentages we obtain the following table:

\begin{tabular}{|c|c|c|c|c|c|c|c|c|}
\hline $\begin{array}{c}\text { Purpose } \\
\text { No. } \\
\%\end{array}$ & $\begin{array}{l}\text { Social } \\
\text { I } 4 \\
35 \cdot 3\end{array}$ & $\begin{array}{l}\text { Sewing } \\
62 \\
19.2\end{array}$ & $\begin{array}{c}\text { Philan. } \\
32 \\
9 \cdot 9\end{array}$ & \begin{tabular}{|c} 
Literary \\
28 \\
8.7
\end{tabular} & $\begin{array}{c}\text { Dramatic } \\
25 \\
7 \cdot 7\end{array}$ & $\begin{array}{c}\text { Secrecy } \\
24 \\
7 \cdot 4\end{array}$ & $\begin{array}{l}\text { Athletic } \\
\text { Io } \\
7 \cdot 4\end{array}$ & $\begin{array}{l}\text { Spite } \\
4 \\
\text { I. } 2\end{array}$ \\
\hline $\begin{array}{c}\text { Purpose } \\
\text { No. } \\
\%\end{array}$ & $\begin{array}{l}\text { Cards } \\
\begin{array}{l}3 \\
0.9\end{array}\end{array}$ & $\begin{array}{c}\text { Relig. } \\
3 \\
0.9\end{array}$ & $\mid \begin{array}{c}\text { Explor } \\
2 \\
0.6\end{array}$ & $\begin{array}{l}\text { Music } \\
2 \\
0.6\end{array}$ & $\begin{array}{c}\text { Language } \\
2 \\
0.6\end{array}$ & $\begin{array}{l}\text { Animal } \\
2 \\
0.6\end{array}$ & $\begin{array}{l}\text { Slang } \\
2 \\
0.6\end{array}$ & $\begin{array}{l}\text { Birds } \\
\text { I } \\
0.3\end{array}$ \\
\hline $\begin{array}{c}\text { Purpose } \\
\text { No. } \\
\%\end{array}$ & $\begin{array}{c}\text { Algebra } \\
\text { I } \\
0.3\end{array}$ & $\begin{array}{l}\text { Hist. } \\
\text { I } \\
0.3\end{array}$ & $\begin{array}{c}\text { Cities } \\
\mathrm{I} \\
0.3\end{array}$ & $\begin{array}{l}\text { Civics } \\
\text { I } \\
0.3\end{array}$ & $\begin{array}{l}\text { Postal } \\
\text { I } \\
0.3\end{array}$ & $\begin{array}{l}\text { Indian } \\
\qquad \begin{array}{l}1 \\
0.3\end{array}\end{array}$ & $\begin{array}{c}\text { Self-Imp. } \\
\text { I } \\
0.3\end{array}$ & \\
\hline
\end{tabular}

Of these clubs 80 or $36.5 \%$ are secret. 
In most cases these clubs are but incidents in the group life of girls already united by friendship and the play activities. This is particularly evident in cases where the same group forms numerous clubs, one succeeding another. One girl writes: "We children were very fond of forming secret clubs and had several at different times. Sometimes I or my sister belonged to two different ones at a time." Another girl reports 5 different clubs. In such cases the club is not the cause of the group formation but incidental to its activity. In other cases, of which the following is a good example, the club is the principal bond of union. "Last spring I organized a club. I wrote to my girl friends inviting them to my house to discuss plans for forming a club, the object of which was to do something to aid the Fresh Air Fund which sends poor children to the country in the summer. The girls were very enthusiastic over the idea and each girl agreed to bring in at least one member. The members were all between the ages of sixteen and twenty and were good workers. After four meetings which were held at my house the club was organized and we decided on different ways to make money." Although these girls were friends they were not constantly together in their activities. The club was extra-incidental and not incidental to their life. In the great majority of cases, $23 \mathrm{I}$ in fact, the descriptions show that the clubs were incidental to the play activity; in the smaller group of 30 cases the activity was extra-incidental. Of these 30,2 were under adult leadership, the only ones in the whole study which were. The medium age of the formation of these groups was I5. Only 8 were under I4; none were under II. The duration of these clubs varied from 3 months to 8 years. The medium duration was 2 years, the average 25.6 months. The membership varied from 4 to $\mathrm{r} 20$, with a medium at 14 and an average of 20 , with an average deviation of 13. The primary purposes were in 9 cases social; in 3 cases each athletic, sewing, literary, musical and religious; in 2 cases each for study of languages and for card-playing, and I case each of clubs formed for dancing, dramatics, philanthropy, and the study of algebra and of history. Secondary purposes of philanthropy in 3 cases, literary activity in 3 cases, social in $I$ case and sewing in $I$ case were present. 9 of them were secret.

As another form of approach to the question the clubs were divided into 3 groups according to age, the 32 clubs of girls under 9 forming the first, or group A, the group of 170 formed by girls between and 9 and 44 inclusive constituting group $\mathrm{B}$, and the 37 cases of clubs over 14 making group $\mathrm{C}$. 
A. The duration of the clubs in group A varied from I week to 3 years. The medium duration was 8 months, the average 9.3 months with an a.d. of 8 . I. The membership varied from 3 to 12 . Of the 26 cases where membership was stated the medium was 5 , the average 5.5 with an a. d. of $\mathbf{r} .4$. One of the largest clubs had 2 boys as members. The following is the order of prominence of the purposes: good time, sewing, dramatic productions, philanthrophy, athletics, spite, exploring, literary and musical occupations and bird study. Of this group I 2 had secret elements.

As an example of the type of club most common among these young girls the following may be quoted:

"When we were about 7 years of age we formed a club called the 'Dramatic Seven.' As the name implies the club was formed for the purpose of having little 'plays.' After we had given one play we changed the names to the 'Merry Seven' and gave parties. Originally there were 7 members, all close friends to each other. As we became acquainted with other children we allowed them to join if we liked them very much. We had a peculiar password, 'two drops.' 'These words were selected because when joining, each member had to go through an initiation ceremony, which consisted in having two drops of salt water dropped on the tongue through a medicine dropper. The club lasted about a year." Other characteristic features are added by this account: "When some of my friends and $I$ were on an average of 8 years old we formed a little sewing club which met Saturday afternoons. This little club, of which we were very proud, was organized for a twofold purpose. First we sewed and embroidered clothes for our dolls, and secondly we had little outings during the vacation time from the money in the treasury. The dues were three cents per week a member, and every Saturday we met at a different member's house. One of the chief and most important things to me was the little spreads which were served after the meetings, by the mother at whose house we held our meetings. As far back as I can recollect we had 6 members, all girls, who were the organizers. No boys were allowed to join our club. We had no password or held no initiation ceremony. Having no satisfactory candidates, and two of our members having moved, our little club broke up after having existed two years."

B. Group B is the largest, including I 7o cases. Duration was stated in 55 cases. The medium was 5 months, the average 9.27 , with an a. d. of 9.08. The number of members in I 52 cases had a medium of 8 , an average of 7.7 with an a. $d$. of 3. 4. These clubs were in half the cases for a good time. The other purposes were found to rank as follows: sewing, 50; philanthropic, 29; dramatic I8; secrecy, I7; literary, I3, athletic, 4 ; religious, 2 ; for the protection of animals, 2 ; and I case each for the study of large cities, and for history, to play Indian, and for self-improvement. Secret elements were present in 53 cases.

An illustration of the social club of 14 year old girls is well represented by this report:

"About four years ago three of my girl friends and I formed a small club. We named it the Weathervane and each of us represented a wind, one 
north, one east, one south and one west. It was an exclusive organization and though we contemplated admitting four members to make northeast, etc., we never did. I was at the time about fourteen years old. Our only purpose in forming it was to have a good time. We met on Friday evenings and always made candy. Sometimes we played games also. Our dues were five cents a week, and they were used only to have a good time. The club lasted for about two years when it was broken up because one of the members went to Europe. During the time it lasted we had one party to which only four were invited. We went on little picnics, but only by ourselves. It was not a secret society so we had no password but we had what we called a club call. It was 'North, south, east or west, which one do you like the best!' We also had a club song which one of the girls composed. Our colors were green and gold and to this day we are all loyal to them. We were going to get club pins but the club broke up before we could decide on them. We kept a book in which the secretary always wrote up the minutes of each meeting. We had election of officers about once every two or three months. Of course each member was an officer."

The following pictures the typical sewing society:

"At the age of eleven another girl and I organized a little club for the purpose of making Xmas presents as well as for pleasure. The club consisted of only eight members and no other person was allowed to join. We called ourselves the 'Sewing Club' and wore black and orange rosettes in order to make people ask questions. We met at each person's house, sewed, had little refreshments and had a general good time. We met once a month. The society only lasted about four or five months. I remember I was secretary of the organization."

This portrays a dramatic club:

"At the age of thirteen I with five other companions about the same age formed a club which we called the 'Dramatic Club.' We would read all the children's stories we could get and then attempted to stage those which we thought were best suited for the purpose. New members were taken in according to what was needed in the cast, and only those were admitted who we thought had the ability. It was not a secret organization and we had no password. The club lasted for one summer and disbanded when school began."

A typical club with philanthropic motivation is this described:

"When I was about twelve years old I belonged to a secret society called the S. B. C. The club was formed to make scrap-books for a hospital, which the sister of one of the members was interested in. Two of us formed the club and we chose three other girls whom we asked to join. This made five of us and no one else could join. We had neither password nor ritual. The club lasted about a year or perhaps a little longer."

What we have called a literary club includes such as this:

"One voluntary organization to which I belonged when about thirteen was a reading club. A list of good books was arranged, each of which was read before the club by each member in turn and then discussed. Our object was to read good books and become acquainted with the life of the authors. New members were freely taken in until we had twelve; that was the final number. We continued our club for nearly a year. All proceedings were kept secret."

C. Of the 37 clubs formed by girls over 14 years of age, 7 were still in existence at time of writing. The reporters 
being juniors and seniors in normal school may be judged to be at least 18 . Figuring on the length of time these clubs have actually existed to date of reporting, the medium duration in months is 12 , the average 20.3 with an a. d. of I2.I. This is figured from the $3 \mathrm{I}$ cases reporting duration. The membership varied from 5 to 40 ; the medium was 10, the average 12.6, with an a. d. of 6.7. Here also there were 31 cases. These were mostly social clubs. The other purposes in order of importance were dramatic, literary, athletic, for the study of a foreign language, card-playing, sewing, religion, philanthropy, music, algebra, civics, saving of postal cards and the elimination of slang. 8 of these were secret.

A comparison of the 3 groups shows that the duration of the clubs in groups $A$ and $B$ was very nearly the same. For group A it was 9.3 with an a. d. of 8.8; for group B it was 9.27 with an a. d. of 9.08. Group $\mathrm{C}$ however shows a great increase, the duration here being 20.3 with an a. d. of I2.I. The membership shows a slight increase with age, the figures in the 3 cases being 5. 5, 7.7, and 12.6. A comparison of the purposes and activities shows that the motive of social pleasure occupies approximately the same prominence in each. Sewing occupies the same position in A and B but it drops considerably in $\mathrm{C}$. The dramatic motive appears in nearly the same proportion of cases in each period. Of the 32 instances in which the philanthropic motive appears all but 6 are in clubs under $13 ; i$. e., $55 \%$ of the cases being under 13 have $81 \%$ of the cases of philanthropic motivation. The literary motive remains of the same prominence in the 3 groups. The athletic purpose which is insignificant, evident in but 7 cases, appears at 10 and over. The motive of secrecy appears as a dominant one in 16 clubs and as a concomitant or subordinate one in 10 others. Moreover 82 have some secret characteristics. The ages when secrecy is a motive for forming clubs is from 8 to 14 . In one case no age was given. Of the 25 others, 18 or $72 \%$ were under I I years of age, while only $21.4 \%$ of all the clubs were under II. All were under I5; half of them were at 9 and 10 . Of those clubs having some secret elements the age was given in all but 2 . There were 3 I under II; i. e., $38.8 \%$. This illustrates the kind of club in which the purpose is secrecy:

"When I was ten years of age six little girl friends and myself formed a secret club, which we called W. N. T., meaning-we never tell. The club was of the most secret character; everything was whispered in order to make it more mysterious. We had no passward but always spoke to each other in 'hog Latin.' The membership of the club was most exciusive since we took in only those whom we especially liked and who would let us run things the way we wished. The only object we had in forming the club was to keep certain other children whom we knew guess- 
ing when we spoke in whispers. The club lasted for about six months. One of the exclusive members told the name of the club and this was the cause of its finally being dissolved." To represent the sort of club meant when we say that it had some secret elements though not formed for the purpose of secrecy as the above, the following may be quoted: "I belonged to a club of sixteen girls and boys. The object was to give performances. Our meetings were secret and our password was 'Bobkin.' We used to give little plays only for our own amusement and nobody outside ever came. . . . This club lasted one summer.

The athletic clubs were evenly distributed through the different ages. The 4 'spite' clubs were under 12.5 years. Those formed for playing cards, for studying history, language, civics and algebra were formed after $\mathrm{I}_{4}$, as was the I for selfimprovement. The kindness to animals motive appeared under $\mathrm{r}_{3}$, as did the 3 formed for bird-study, the study of cities and for playing Indian. The religious motive appeared at II, I 2 and I 7 . Self-improvement appeared in I case, at I4.

As to frequency of meeting, 103 furnish data. Of these, 3 do not furnish the age of members. In ro cases meetings were more frequent than once a week; in 63 they were once a week, and in 24 less than once a week. Of those meeting more frequently than once a week all but 3 are under 12 years in age; all but 3 of those meeting less frequently than once a week are over II; all are Io or over.

Data was furnished for II 5 clubs as to the basis of membership. In 42 cases the membership qualification was just the fact of being playmates or neighbors; 37 were described as cliques; the basis was attendance at a certain school or membership in a certain class in 12 cases; in 12 , new members were voted into the club, in I case by majority, in 7 by unanimous vote, and in the others the statement merely was that new members were voted on; in 9 a literary or musical test was given; in I the qualification was the possession of pretty clothes; in 2 cases the club was declared to be open. Grouping all those whom we may be reasonably sure were exclusive, $i . e$., the cliques and those admitting only by unanimous vote and the I having the qualification of dress, the total amounts to 45 , or $39 \%$. of the whole. Comparing the number of cases of clique organization for each age with the total number of clubs at that age, the following percentages are obtained, corresponding respectively to the ages 7 to $18: I_{14}, I_{1}, I_{3}, \mathrm{II}$, $10,16,27,27,33,20,33$, 10o. Although a rise is evident in the frequency of cliques at 13 , the difference between the earlier and later years is not very remarkable. The last figure, it is to be observed, is for the only club formed at that age.

From a section of the country entirely isolated from that whence these normal school girls came have been obtained data of a similar nature. Miss Clare Lyon, Principal of the Lidger- 
wood, N. Dak., High School, asked the members of her English classes to describe what clubs, if any, they had ever been members of. The instructions were similar to those Prof. Monroe gave. There were 27 members in the Senior and Junior classes, of whom 23 were taking English, 18 girls and 5 boys. All but 2 of these had belonged to some sort of club or 'bunch,' but 9 of these show adult leadership. The others, 9 girls and 3 boys described spontaneously formed clubs. Out of 18 girls, therefore, $50 \%$ had been members of spontaneously formed clubs, The ages at the time of formation varied from 9 to 14 , the number of members from 4 to 15 , with an average of 6 . The average duration was 7 months. The purpose of organization was predominantly for a good time, lesser in importance being the purposes of sewing, card playing, reading, dramatic productions and philanthropy. One question asked was their preference: to have a chum or to belong to a club. Replies were received from I I, 9 of whom preferred to belong to a club; 2 preferred having a chum. The fact was disclosed that there was no conflict between the two sorts of relationship however. The typical situation may be described thus in the words of one of the girls: "Here in this town I have belonged for quite a while to what is known as the 'Bunch,' and besides have always had one particular girl as my chum." From various sections of the country have been gathered other data of a confirmatory nature but of too disconnected a character to be classified.

It will be well here to summarize the facts thus far presented regarding boys' and girls' group activities. At the age of 5 or 6 children get together in their play. These groups are roughly organized and they participate in unco-operative and unorganized games which gradually shape themselves into definite games with rules, this germinating period lasting until puberty. This gang activity may continue until maturity unless the group is organized into a club. The club makes its appearance as early as 7 or 8 , both with boys and girls. Of the spontaneously formed clubs reported by Sheldon $45 \%$ were of girls. Of the girls in Prof. Monroe's classes 91\% had been members of clubs. In a personal letter from Miss C. I. MacColl, of Christodora House, a settlement on the lower east side of New York, the statement is made that "girls in our neighborhood group as do the boys. In the past three months I have had applications from fifteen different groups of girls from fourteen to twenty years of age wishing to come to Christodora as organized clubs." The ages when clubs were most frequently found among boys were Io to I4; this corresponds with the time when they are most often formed among girls. After that age they do not cease to be members of clubs but they 
usually join organizations which they find already in existence, the permanent adult or student clubs. The number in the gang averages 9 or 1o. We have no figures on the size of the boys' club, but as the gang organizes itself into the club we may infer that the two are the same size. The girls' clubs were found to average 8 members, they increase in size with age, the adolescent clubs having an average of 12 . In external formation, then, boys' and girls' clubs are very similar. The difference between them is in their activities and purposes. This correlates closely with the fact that clubs formed before the age of 13 or 14 are but incidental to the regular group activity. Nine tenths of the clubs reported by the normal school girls were of this character. Boys' clubs spend their time mostly in physical activity; girls have clubs for sewing, dramatic productions, tea parties and social good times. Girls say that they form clubs for a good time; boys say that they are for baseball, which is saying the same thing since boys play ball for a good time. The activities of either sex could be carried on without the club. 'In girls the exclusive clique spirit is stronger than in boys. Secrecy is prominent among girls under I I years; it is not so strong among boys. After the age of 14, clubs appear which are not mere incidents in the play life; a new basis of membership is introduced.

\section{Chap. III. Student Societies}

Student life offers a volume of material for the study of social psychology that has scarcely been opened. Nowhere can the psychology of later adolescence be more profitably studied than in the group life of students. Pres. Hall says: "Student life is perhaps the best of all fields, unworked though it be, for studying the natural history of adolescence. Its modern record is over eight hundred years old and is marked with the signature of every age, yet its essential features do not vary" (35, p. 399). The I 7 pages following this statement in "Adolescence" summarizes a great many of the facts of these student societies from the nations of Bologna and Paris to the modern college fraternity. It is necessary for us in this study, so far as the presentation of data is concerned, to confine ourselves to present-day. American societies. First to be considered are the societies of the preparatory and high schools.

The first fact to be observed is that the conditions prevailing in the public high schools are very different from those found to exist in private boarding schools or the preparatory departments of colleges. In the latter case the organizations among the students approximate quite closely those in the college. The group organizations chronically present in the high school 
are the class, the literary and debating society, the athletic association, the glee club and orchestra, and less frequently mandolin, dramatic, art, camera, craft and science clubs, publication boards and fraternities. Generally the classes organize in a rather loose way and for special occasions, for the furtherance of class and school interests. In some cases only the senior class thus organizes with officers and committees and perhaps a constitution, for the purpose of managing the commencement affairs. Besides the clubs distinctly of high school students smaller group organizations are formed, as was shown in the preceding chapter. These are not characteristic of the high school but of that period of adolescence. The literary and musical societies, except in the larger places, are as a rule under the directing hand, if not propelled by one of the instructors. The athletic clubs, at least among boys, are more truly spontaneous. In this case, however, the faculty have usually found it advisable to associate themselves in an advisory capacity and often as financial managers.

The last twenty years has witnessed the formation of secret fraternities in the high school. As to their prevalence at present it is only possible to approximate as there are no figures. Baird merely says: "They are numerous, but have, except in a very few instances, little elements of stability, and in fact are imitations of the mere externals of the college fraternity system without really grasping or living up to its principles of brotherhood and mutual helpfulness" (6, p. V). The difficulty of determining their prevalence is because first, in but half the cases are they national organizations, and second because of the circumstance that, on account of the opposition to them on the part of the school authorities, secrecy is a means of protection. The report in November, 1904, of a committee appointed by Pres. Harper gives the best idea of their prevalence in the Middle West. Questionnaires were sent to 464 schools; replies were received from 306 ; of these "about I 70 had no fraternities" (73, p. 3). Complete answers were received from only 19 private and 71 public schools. The private schools, having an enrollment of 2,207 , had a fraternity membership of 796 or $36.06 \%$. The 7 I public schools, enrolling 54,827 had a fraternity membership of 4,523 or $8.35 \%$. The number of fraternities per high school varied from i to 6 ; in many schools there was but I sorority. Two exceptional cases were noted; the San Francisco Girls' High School had 7 sororities; The Central High School of Toledo, O., had 9 fraternities and 5 sororities. The average fraternity membership was found to be 30 whether the school contained roo or I,500 pupils. The only difference is that in the larger schools there are more fraternities (73). A couple years earlier 
Gilbert B. Morrison sent out inquiries to 200 high school principals in the largest cities of the country. Answers were received from 185 ; of these 87 reported experience with fraternities, and 98 reported having had no experience (55). The conditions in New England in 1904 were reported by a committee of which C. T. C. Whitcomb was chairman. He received replies from 244 out of 301 requests for information sent to towns in New England and to a number of large cities throughout the country. Fraternities were reported as existing in 72 schools (86). A committee of the Y. M. C. A. sent out a few questionnaires in igo8. They received replies from 48 high schools in Massachusetts and Rhode Island. Of these I 5 have fraternities; 33 have not. The average membership in these societies is $26(89)$. All of these reports record the opposition to the fraternity in the high school. Indiana, Kansas and Minnesota by legislative acts in 1907 sought to abolish them. These papers name 22 cities that legislated against the fraternity.

College societies are more familiarly known. As Sheldon pointed out in his book on college societies, where the elective system has been introduced, it destroyed the autonomy of the class, which had until about 1880 been an important factor in the social life of the American college $(68, p$. 196). In the smaller colleges the class organization is still quite strong. Through the machinery of its constitution, officers, and committees it conducts 'proms,' banquets, parties, the year-book, dramatics, etc., and crystallizes a class spirit which vents itself in the inter-class athletic and debating contest and develops a subtle loyalty to 'noughty-several.' To enumerate the different kinds of organizations which students form would be to duplicate every type of adult club and then add a good many others such as students only form.

Michigan University has a total of 176 student organizations including 20 fraternities in the literary department, 13 in the professional schools, 9 sororities, each having its own house, Io sectional clubs, 6 literary and debating societies, 6 musical clubs, dramatic, athletic, military, honor societies, class organizations, press and publishments, and general university clubs, such as medical, socialist, woman's suffrage and Christian associations. Wisconsin University has 130 such organizations (7 I, pp. 208, 228).

A few of these types of club deserve special attention. The last edition of Baird's handbook on secret fraternities (6) issued in 1905 names 31 general chapters for men, I for women, 50 professional fraternities, (about 10\% of whose membership is duplicated in the general fraternities) and local fraternities to the number of 70 for men and 47 for women, 
with a total membership of 242,501 . The World Almanac of I9I I (88) gives larger numbers in each case, the total being 329,4 I 7 . It is evident that this number includes alumni, as the total student body in universities, colleges and technical schools in the United States is only 289,204 (88) and that in Canadian schools is only 10,000. Besides the secret fraternities, there are general honorary societies bearing Greek letter names. All are copies of Phi Beta Kappa which now has a membership of 15,000 . The peculiar features of the college fraternity are: (I) their residential character; they provide a substitute for the home atmosphere by furnishing a house exclusively for the residence of the society members; (2) their secret features; (3) the extreme care taken to choose members of congenial interests.

Religious organizations are found in all colleges. That of widest extent is the Y. M. C. A., which numbers $75^{8}$ organizations with a membership of about 60,000 . The eastern schools have other religious societies and denominational clubs. Athletic associations, to which the greatest part of the students belong, are universal. Their purpose is to furnish financial and moral support for the teams. Lack of space forbids further details as to student organizations. Pres. Hall, in one of his remarkable sentences of 20 lines, summarizes the different kinds of clubs found in colleges $(35$, p. 4I6).

\section{Chap. IV. Adults Clubs}

Much valuable data would be provided for sociological as well as for psychological interpretation of the club were we to trace the history of its development. As student life is the great laboratory for the study of later adolescent social nature, so the club life of adults reveals the working of the social processes of maturity. The difficulty of this task is that there can be found no beginning until the earliest human life is unearthed and laid out for inspection, and even then we would be referred to higher animal life. All that the limits of this thesis will permit is an outline sketch of the growth of the club in America, with a presentation of the main facts regarding the most prominent representatives of the types now existing.

In 1800 there were but few clubs in this country. Freemasonry had been introduced from England between 1723 and 1740 . In 1743 the American Philosophical Society was formed. In 1 764-5 the Sons of Liberty, a secret political organization, was founded. The New York Chamber of Commerce, the first prominent representative of the business club, was organized in 1768 . The date of the Phi Beta Kappa was 1776. The Pennsylvania Prison Society, 1787, the Massachusetts Historical Society, 1791, and the Connecticut Academy of Arts and Sciences completed the 
list of important learned societies. The officers of the disbanding army formed the Society of the Cincinnati in 1783 . As a corresponding and rival society was formed the Society of Tammany in 1789 . The first woman's club on record was the Female Society for Relief and Employment of the Poor, Philadelphia, 1798 . In the next 30 years the growth was not very rapid. The principal organizations of this period were the following: The New York Society of Journey men Shipwrights, 1803 , had some of the characteristics of the labor union. The American Board of Commissioners for Foreign Missions, 1810, started the great missionary movement. The Society of Red Men, I813, developed out of the Sons of Liberty. OddFellowship was introduced from England in 1819. 1826 was the birth year of the National Academy of Design and the Society of the War of 1812 .

The period from 1830 to the Civil War saw the birth of many reform movements which worked through clubs. Women now make their influence felt as never before in history. Labor unions sprang up, and political clubs were numerous. They had no small influence in crystallizing action in support of the principles that rent the union. The leading women's organizations of this period were the Ladies' Association for Education of Females, Jacksonville, I11., I 833; the Female Anti-Slavery Society and Home for the Friendless, 1834; the Daughters of Temperance, 1840-50; the National Woman's Rights Society, Nauvoo, Ill., I 842; the Ladies' Physiological Institute of Boston, 1848, and the Woman's Equal Rights Union, Seneca Falls, N. Y., 1848. Many local labor unions were organized, and the first national union, The International Typographical Union, I850. Other unions of more than local importance were the New England Workingmen's Association, the New England Protective Union, and the Industrial Congress of the United States, all formed in 1855 . The National Education Association was started in 1857 . Several secret societies of a fraternal nature were organized and two were introduced from England,- the Ancient Order of Foresters, 1832 , and the Ancient Order of Druids in 1839 . In 1842 the Sons of 'Temperance and in I843 B'nai B'ruth, a Jewish secret society, were organized. There were over forty learned societies formed during the period, principal among them being the American Association for the Advancement of Science, 1857. There were several important political societies of short duration.

By far the great majority of societies existing to-day have been formed since the Civil War. The fraternal insurance society movement may be said to have been begun by the Ancient Order of United Workmen, in 1868. Since that date have been formed over 600 on a similar pattern (54). The same year was the birth year of the 'woman's club' movement, starting with Sorosis of New York and the New England Woman's Club of Boston. In 1868 the National Labor Union, formed two years earlier, reached an aggregate membership of 640,000 . Though it declined, its task was taken up by the Knights of Labor, founded in 1869; its aggregate membership was 702,924 in 1888 (40, p. 379). This organization in turn lost power and the American Federation of Labor, 1881, took up the mantle. The scientific societies as well began their modern epoch after the war. The great organization of farmers began in 1867 when the National Grange of the Patrons of Husbandry was founded. The growth of societies has continued constantly, each year adding a greater number of new organizations. Meyer says that of the 568 fraternal orders, the date of whose organization could be obtained, 78 only were formed before 1880,124 between 1880 and 1890 , I 36 between 1890 and 1895 , and 230 between 1895 and 1900 . The number of clubs of all kinds continues to grow by geometrical progression. The Handbook of Learned Societies (I6) gives the dates of practically all the learned societies in America, except those in the fields of medicine, agriculture, local bar and teachers' associations, leagues for civic improvement, charitable organizations and patriotic societies. Detailed data are given for 431 national and local societies of the United 
States. Of these 5 were formed in the period 1740-1800; $11,1800-30$; 49, 1830-60; 24, 1860-70; 54,1870-80; 90, 1880-90; 114, 1890-1900; $84,1900-08$.

Considering more specifically the different types of clubs now found in America, we may commence with the fraternal order.

The aggregate membership in secret societies according to the World Almanac (88) is over $11,000,000$. This does not constitute one eighth of the population, as might be supposed, because most of these people belong to several societies. The age of admission to membership is as low as 15 in a few, is 16 in a great many and 18 will admit to the majority of fraternal orders. The oldest of these is the Ancient and Honorable Society of Free and Accepted Masons, which has existed in its present form since 1717 (76). Outstripping Freemasonry in membership is the Independent Order of Odd Fellows. It dates from 1739 in England. Two other important societies were imported, the Foresters and the Druids. The Knights of Pythias, the Elks, Knights of Columbus, Order of Good Templars, and the Sons of Templars added to the four above, make up the group of societies which do not have insurance features. Their aggregate size was in 1907 four fifths as large as those having insurance features. This group may be classified as charitable, benevolent, religious or philosophical and mystical.

The majority group of fraternal societies pay sick, death, disability or other benefits. The largest of these is the Modern Woodmen of America, founded in 1884 ; it now has over $1,000,000$ members. The purpose of all these fraternal orders, whether with or without insurance features, is mutual helpfulness. In organization they have the peculiar features introduced by secrecy, ritualism and mystic rites.

As was said above, the 'women's club' movement started in r868. We use the quotation marks to designate the peculiar meaning attached to this type of woman's society, which Mrs. Harper says women "formed purely for their own recreation and improvement" (75, p. I043). This does not characterize the woman's movement as a whole, however, and the societies which started with this narrow spirit "widened by degrees into a study of practical matters related to law and economics," so that to-day the General Federation of Women's Clubs, representing a membership of over 500,000 , has committees on art, child labor, civics, civil service reform, education, forestry, household economics, industry, legislation, library extension, literature, pure food, reciprocity and other topics. Besides this large federation there are many other organizations of women, only a few of which can be mentioned.

The National and the American Woman's Suffrage Associations were founded in 1869 and united in 1889 . The Woman's Christian Temperance Union was founded in 1874 for securing the abolition of the liquor traffic. Its scope of work is so broad as to require 40 departments. Its membership, including children's societies is about half a million. Other societies of national importance constituted entirely of women might be mentioned in almost every field of endeavor. Some of these will be mentioned in the following paragraphs. Fraternal orders have female almost as frequently as male members. 
Philanthropy as an organized movement of national scope culminated in 1873 when the first National Conference of Charities and Correction was held.

This organization now numbers between 2,400 and 2,500 members, and represents all phases of philanthropic and charitable work. There are several societies working for international peace. The Lake Mohonk Conference on International Arbitration was founded in 1895 . The National Municipal League, 1894, enrolled in 1909 in 168 organizations reporting 163,473 members. The American National Red Cross Society was incorporated in 1905. It is a systematically organized body for furnishing relief in disasters of national scope. In 1911 it has a membership of 15,000, organized into local chapters, and has an institutional affiliation with is associated charities. The National Civic Federation founded in 1900-or has as its purpose the co-operation of the best brains of the country in an educational movement toward solving some of the great problems related to social and industrial progress. It has an executive committee of over 50 leading representatives of capital, labor and the public at large. The National Conservation Association was organized in 1909 to fight for the prompt and orderly development of our natural resources. It is a separate organization from the National Conservation Congress, formed the same year, though the two work harmoniously.

\section{Of slightly different nature, as far as basis of membership} is concerned are the educational associations.

The National Education Association, formed in 1857 as the National Teachers' Association, assumed its present name in 1870. This is the official society of the teaching profession, and has as its purpose the elevation and advancement of the profession. On Dec. I, 1909, it had a membership of 10,964. The Chautauqua Literary and Scientific Circle was founded in 1878 with the aim of continuing the influence of the Chautauqua Assembly throughout the year in all parts of the country. Since that time more than 260,000 members have been enrolled. The Association of Collegiate Alumnæ was formed in 1882 for the purpose of uniting the alumnæ of different institutions for practical educational work. Dec. 1, 1909, the number of regular members was 4,377 .

More specific in character are the societies for science, literature, and art.

The American Association for the Advance ment of Science had its first meeting in 1848 in pursuance of a resolution adopted in 1847 by the Association of American Geologists and Naturalists. This is the most comprehensive of American scientific societies, having an enrollment in roro of over 8,000 members, in I I sections, and an affiliated relationship with about 30 societies within the scientific professions. A more exclusive organization is the National Academy of Sciences, incorporated by congress in 1863 . There are now 115 members and 44 foreign associates. In the National Academy of Design there are 138 national academians and 124 associate national academians. The American Academy of Arts and Letters dates from 1904. Its first members were selected by 7 men, chosen by the National Institute of Arts and Letters from its own body, with authoriy to select the other members of the Academy until the number should reach 5o. The National Institute was organized in 1898 at a meeting of the American Social Science Association, the qualification for membership in which is 'notable achievement in art, music or literature.' The number is limited to 500. The American Social Science Association was organized in 1865, 
its field being the investigation and discussion of all subjects pertaining to the progress of human society. It has a membership of about 1,000 . A similar society, founded in $\mathbf{1 8 8 9}$, is the American Academy of Political and Social Science which has about 4,000 members.

\section{Several special religious societies deserve attention besides} those organized with churches.

The churches in 1910 had an aggregate membership in the United States of over $34,500,000$. Part of the church work is conducted by specially organized missionary societies. There is no separate membership in most cases. The members of the American Baptist Missionary Union for instance, are all members of the Baptist Church. Auxiliary societies of women exist in which money payments corresponding to dues are sometimes expected. The point of view in these religious societies is different, however, than in any other form of club, or than in the Young Men's Christian Association, where a regular payment is made in turn for certain privileges. The Y. M. C. A. was founded in England in 1844 . The Boston and Montreal Associations were founded in 1851 ; the first national convention in America occurred in 1854. At present there are in North America over 2,000 associations with an aggregate membership of 500,000 . The Young Women's Christian Association started in England in 1855. In this country the organization was formed in $185^{8}$ as the Ladies' Christian Union.

The patriotic societies in existence before the Revolution may be said to have been largely political in character.

The Society of the Cincinnati was the first of that group now prominent that have as a basis of membership an hereditary qualification. The World Almanac of 191 I mentions 32 such organizations for men, I I for women, and 4 that have a mixed membership. The chief military organizations are the Society of the War of 1812 , formed in 1826 , the Aztec Club of 1847 , the Grand Army of the Republic, I866, which in I 910 had 213,901 members, the Sons of the Revolution, 1875, the Sons of Veterans, 1879, and the Societies of Spanish War Veterans. In 1883 the Woman's Relief Corps, Auxiliary to the G. A. R., was formed with the object especially to aid and assist the G. A. R., and to perpetuate the memory of its heroic dead. It had in June, I910, I64,255 members. In 1890 was started the group of societies which employ this hereditary qualification as a means of obtaining an exclusive membership for social purposes. In the same summer were formed the Colonial Dames of America, and the Daughters of the American Revolution, the latter being the more influential of the group, having in 1910 a membership of 60,250 . The characterizing feature of these clubs is not their purpose but their eligibility test.

Most of the labor unions of the country are affiliated into the organization known as the American Federation of Labor.

In r9ro this was composed of 122 national and international unions, with an aggregate membership of $1,534,700$. In the railway unions not affiliated with the federation were $282,136 \mathrm{men}$, and in the other independent unions 138,688 . Besides these there are several organizations such as the Knights of Labor, the American Labor Union, and the Western Federation of Miners, from whom no figures could be obtained. The estimated trade union membership in the United States and Canada for 1909 is 2,500,000 (57, p. 404).

At the time of every political campaign local political clubs spring up everywhere in all parties. 
In the two leading parties there are strong permanent organizations of a central character. The National Republican League of the United States was organized in 1887 by delegates from about 350 local clubs, its aim being to enlist voters for the party. It has a membership of $1,500,000$. A similar organization in the Democratic Party, now in its third year, has 875,000 members.

National organizations exist in many of the professions.

The American Medical Association was incorporated in 1897 and has a membership of 35,500 . The American Bar Association was organized in 1878 and now has 4,000 members. From these it is but a step to the professional organizations of business men. The American Iron and Steel Association is classed by the Carnegie Institution as one of the learned societies. It was founded in 1855 to take all proper measures for the advancement of the trade, and its membership is constituted of manufacturers of iron and steel. The same handbook includes the American Railway Master Mechanics Association, 1868, founded for the advancement of knowledge useful for this trade. The National Association of Manufacturers, 1895, is but the most general of 500 employers organizations that might be named. Corresponding to every degree of organization of labor exist organizations of capital. So on down the list we might go, if there were paper enough, to enumerate the clubs of governors, bankers, accountants, commercial travellers, clerks, pickpockets, thieves, tramps and 'blackhanders.'

Another type of organization is represented in the athletic associations.

These exist locally in almost every city in every branch of athletics. For the last 20 years amateur athletics has centered in the American Athletic Union, which now represents in active membership over 400 local clubs, and as allied members ro national associations, the aggregate membership amounting to about $2,000,000$ competing athletes. It was organized in 1887 and after a war of several years with its predecessor, the National Amateur Athletic Association of America, which was founded in 1879, the latter was absorbed.

A society in a class by itself is the National Grange of the Patrons of Husbandry, 1867. It admits women on an equality with men. Its purpose is to promote all that is best in the mental, social and spiritual development, as well as to advance the material interests of its members. Local granges have been formed among the farmers of every section of the country. In numbers it reached its greatest height in 1875 , when there were $1,500,000$; this was the result of the panic of 1873 . At this period the society got into politics with disastrous results. At present it confines its activities to educational and social wrok.

In the above treatment the aim has been to describe the chief facts regarding the most prominent representatives of all types of the club. Most of these have been national societies. Connected with each are local organizations, formed on a similar plan. In thousands of cases, however, there are local clubs entirely independent, and each varying from the others. Foremost among these is the 'social club' formed in every town. Where there is wealth enough a club house is built. The World Almanac gives the names of 76 such clubs in New York City, which have a membership of 
75 ,ooo. The chief purpose in the social club is a good time and the agencies employed are almost as varied as human interests. In the way of summary of the adult clubs nothing can be said but that for every conceivable object a group of people may have in common the American tendency at present is to organize a club.

\section{SECTION II. INTERPRETATION OF THE DATA}

\section{Chap. I. The Dynamic Mental Forces which Produce the Club}

Thus far this thesis has confined itself to a presentation of the facts regarding the club, $i$. e., to the structural aspect of social psychology. This section of the paper attempts an interpretation of these "data, which process constitutes the functional aspect of social psychology. In the genetic approach to this question it is possible to see the development of the different psychical processes involved. The task of this chapter is to describe the dynamic mental processes which produce the club.

It will be helpful first to draw a distinction between the activity of the group and the form of organization of the group. The activity has its causal plexus more firmly established and developed than does the form of organization. The needs of the human race do not change with every wind of fad, but are fundamentally the same in all groups throughout ages. In studying the activities of boys' and girls,' men's and women's clubs we find at base the innervating cause that has inspired the group life of ages. On the other hand, the fraternal beneficiary organization, the woman's club and the societies of boys and girls have a form quite modern. Moreover the universality, in America at least, of membership in clubs of one kind or another, is one of the facts sociologists have found remarkable.

There are but three kinds of self-activity: play, work, and drudgery. (I am following here Dean Thomas M. Balliet, as he treats this subject in his classroom lectures.) Some things are interesting in the doing without reference to what results from that activity; this is play. Work differs from play in that it has an end that is desirable. The activity itself may be interesting or uninteresting; the distinguishing feature about work being that it is performed for the sake of an end. Drudgery is unpleasant activity which accomplishes nothing; the doing and the result are both painful and useless. In studying the activities of groups we have to consider only the first two. A society based on drudgery 
cannot endure. I would go beyond Dr. Balliet here and classify play on the instinctive level of activity, and place work on the reflective level. The most fundamental instinct any organism has is activity, just pure movement for its own sake. Our definition of play, therefore, makes it fundamentally instinctive. The new element added to activity which makes the compound work is forethought, the idea of end, deliberation.

This classification of self-activity is directly applicable to the study of group life. Up to the age of fourteen, on the average the club organization was found to be purely incidental to the play life of a group already formed. After that age it was clearly evident that ulterior purposes were motive powers for bringing together a group. The transition is not abrupt. The first appearance of reflection in group life is made in groups originally ruled by instinct. What can be said is that boys and girls do not deliberately form groups for an ulterior purpose until about the age of fourteen. The appearance of the reflective process in group life by no means banishes the instinctive. In fact in all life the reflective is a secondary motive. Especially is this true of club life, a type of life which is in general only possible when the day's work is over. It is in the club that adults get themselves back into the play attitude of childhood.

The motivation for the activity of group life is then either instinctive or reflective or both. A consideration of the content of the activity introduces another functional process, namely contagion. The content of play is in part recapitulation, $i$.e., so far as it is instinctive. A clearer statement of the function of recapitulation, however, would be to say that, in so far as an individual resembles his ancestors, as the result of an instinctive Anlage, he will act as they do, and that in general the individual tends to pass through the stages of development that the race has traversed. Because of the fact that a great part of the literature dealing with the club misinterprets recapitulation it seems necessary to interpolate a statement of our position. The chief error has been due to the fact that primitive life has been misinterpreted. If modern anthropologists be correct primitive man was not so savage and gorillalike as, à la Jack London, we have been wont to conceive. The savage is pretty close to the intellectual leader of our civilization, if we but take the latter on his unguarded vacation moments. The Englishman enjoys hunting and fishing as much as does the savage. The American college professor approximates the life of the Indian just as closely as he is able, when he gets a chance. The main difference is in the degree of complication and organization of his social life. The 
primitive man lived under an economic régime where there was no factory system nor complicated social structure, but his was the first hand contact with nature. His struggles, which were the same as the civilized man faces, were met with different tools and in a different degree of organization. The two men, the primitive and the present day man were fundamentally the same. To use Prof. A. F. Chamberlain's phrase, both are 'generically human.' The boy of to-day is an Indian in the sense that he is an uncivilized man; he has n't become a $\operatorname{cog}$ in the great economic or moral system. Psychologically the chief fact is that the boy's moral sense has not reached the point of development where he can understand his relationship to the larger social group. We say he is a 'little savage.' We mean that he is in that period of growth when, the power of reflection appearing, all previous standards of conduct which before have been accepted unreflectively, now come to the bar of individual judgment, and the first reaction is a revolt, an insurrection against the moral order. The truth in recapitualtion, if these facts be correct, is then that the individual does recapitulate the race history, but our history has been misinterpreted.

The viewpoint of recapitulation provides an explanation of many of the more individualistic activities. In boys the life of woods and field and stream with its hunting, swimming, fishing, building of huts, tents and dug-outs, the exploring of caves, trapping, skating, coasting, making boats, and in girls, keeping house, making clothes for and caring for dolls, making mud pies and similar activities may be considered as motivated from the great instinctive or recapitulatory power house.

The organized games such as baseball, football, hockey, cricket, basketball, as well as tag, duck on the rock, prisoner's base and the scores of similar games, and in girls' activities croquet, keeping store, playing church, jump rope, clap-in and clap-out, these, and the other group games of similar nature involve in the consideration of their content the factor of contagion, using that term to include both imitation and suggestion. By far the greatest part of the content of the activities of pre-adolescent clubs is the result of imitation of the activity of others, or is the effect of suggestion by others. A curious misinterpretation is recorded above in Sheldon's treatment of clubs. The period before ten he calls that of imitation, that from ten to fourteen he calls the period of invention and the following of instinct. As illustrating imitation he describes the experience of a group of school children. The teacher read an Indian story; all the next winter the children played Indian. This correctly enough he interpreted 
as imitation. A group of thirteen year old boys, however, formed a Jesse James gang (Sheldon makes the parenthetical statement that tales of this notorious leader were rampant at the time). This he interprets as showing reversion, the following of instinct. Certainly the latter case is as truly imitative as the former; both are in fact good examples of imitation. Such is the correct interpretation of all Indian games. Recapitulation will explain the love of outdoor life, but it will not explain the wearing of feathers, the shaping of tomahawks or of bows and arrows. Recapitulation will explain such predatory activities as stealing apples and watermelons, but it cannot be used to explain the organization of bands of desperadoes of robbers, pirates and military companies.

As illustrating the power of contagion in determining the content of girls' club activities the following may be cited:

"When about twelve years old I formed an organization with about eight other girls of my own age. We called our society the Chrysanthemum Society, and our object was to help if we could the little heathen Chinese children which we had heard and read so much about. This was a purely voluntary organization, no one knowing anything about it at first with the exception of the members. We had, I remember, a meeting once a week for about two weeks. In these meetings, which lasted about fifteen minutes, we would have some verses read from the Bible. I remember that I was always anxious to be the one to do the reading from the Bible. After this each one would read some short article concerning the children in China; then we would discuss what we intended to do to help them. We finally decided to hold a fair. This we did and sold lemonade and cake. We invited all the boys and girls that we knew in the neighborhood. They knew nothing about our society until the day of the fair. What little money we managed to get from the fair we gave to our Sunday School teacher, who was greatly surprised when she heard what we had done. I think that our organization did not last over two weeks. We finally grew tired of it and abandoned it."

From among a large number of others this illustration may also be given in full:

“The first club to which I belonged and which was formed by my playmates was the 'Sewing Club.' We five little girls, about eleven and twelve years old, were greatly absorbed in sewing -either embroidery of small pieces for ourselves or the tiniest of doll's clothes. There were no other girls admitted to this club, because the other girls whom we knew were not interested in sewing as we were. Then, too, the club changed its real purpose and it became rather a secret society. The club was started about the beginning of the summer vacation and toward the end we decided we had enough doll's dresses. Just at the time there had been many interesting reports concerning the society people of New York . We talked about these events at our club meetings and finally decided we would pretend we were these wealthy people. Each chose her favorite name for herself and her husband and thereafter we called our club the 'Fourhundred Club.' The chief object of this club seemed to be to imagine ourselves in all the positions of our respective rôles-attending grand balls, theatre-parties dinners and the like, with the gowns and everything appropriate which we 
could imagine. Being thoughtful children as well as very imaginative we did not forget the poor people of whom we heard much from the conversation of our elders. In our imagination we gave bountifully to charity and to all who came in our path. To be sure, in our real life, we knew we never could do so much as this, but to me at least, it was a pleasure beyond that of the beautiful gowns, to think of some one who might be able to do it. Our only passwords were our assumed names. This club continued for about two years and even after two of us moved away from the town we continued it in our letters."

As Sheldon made the mistake of calling the period from ten to fourteen predominantly that for the following of instinct as a determinant of the play content, so also he was incorrect in calling this the period of invention. Invention or the contribution of original interpretations to situations and phenomena are not the product of minds that do not deliberate, and deliberation in the preadolescent bespeaks the precocious child. Deliberation as a process in the formation of the content of play seldom occurs before thirteen or fourteen. When it does appear it completes the trio, instinct, contagion and deliberation, which constitute the determinants of the content of the activity of the group.

Our treatment of the development of the form of the organization of the group is quite closely related to Baldwin's study of "The Basis of Social Solidarity" ( 9 and 8). He differentiates three modes of collective life: (I) the instinctive or gregarious; (2) the spontaneous or plastic; (3) the reflective or social proper. The first is the gift of physical hereditary. The second is the result of social transmission, an emotional response to a social suggestion, its laws being imitation, suggestion, contagion, spontaneous union in common experience and action. The third is the mode of conscious intention, of intelligent judgment, the force which leads people to rebel against the authority of society and the rule of plastic suggestion. The first mode of collective life is illustrated in the family life of animals. The crowd following the leader is the typical example of the second sort; the committee, the legislature, the administrative bureau represent the third type of organization.

Baldwin does not apply this schema to the interpretation of the club, but gives us a point of departure. If we may broaden the instinctive element, gregariousness, to include the additional factors involved in sociability, the resultant complex will satisfy our conception of the forces which produce the club. Sociability is one of the sentiments, using the word sentiment as Titchener defines it: "The sentiment represents the last stage of mental development on the affective side, as thought represents the highest level of development on the side of sensation and image"' (76, p. 499). Sociability is gregariousness evolved to the level of a sentiment. 
The affective element in gregariousness is made evident by a feeling of uneasiness in isolation from, and a feeling of satisfaction in the physical presence of one's kind. As Kropotkin has shown by a wealth of illustration (47) gregariousness is a common instinct of higher animals. He says: "The necessity of communicating impressions, of playing, of chattering, or of simply feeling the proximity of one's kindred living beings pervades nature, and is as much as any other physiological function, a distinctive feature of life and impressionability" $(47$, p. 55). A classic description of gregariousness is given in the "Inquiries into Human Faculty" (28, p. 68-8I) where Galton relates his experiences with the South African oxen. Two processes, at least, contribute to the development of gregariousness, association for protection against opposing enemies and elements, and association in play, the activity of the leisure hours, perhaps, when the demands of eating and fighting have slackened. The resultant legacy left to man from this gregarious association of animals is an instinctive pull toward the company of other men. In its lowest form it expresses itself as the joy of being in a crowd. The professional entertainer recognizes this and throws out inducements to draw the crowd, because the crowd is in itself an asset, even when it spends no money. One of the greatest attractions of Coney Island is the fact that there one will be in a crowd. Gregariousness explains why on election night or New Year's Eve in the great city multitudes of well educated people find themselves irresistibly drawn to the streets where the crowd is thickest. There is a feeling of exaltation and exhileration that sweeps over one when in a crowd that has a charm all its own, because it satisfies a primal need. McDougall attributes the growth of cities far beyond the point of optimum economic efficiency to this instinct (4y, p. 29630I). Ross writes: "These instincts (gregarious) appear as craving for the presence of one's kind, distress at being left alone, nostalgia after separation from mates, and a capacity for social pleasure indicated by mirth, laughter and festal impulses. They lead to social amusement, play, games, dancing, feasting and intercourse. These in turn foster friendly interest, spontaneous helpfulness and a sense of solidarity" (65, p. 14). As is suggested in this statement the concept of the consciousness of kind, in Giddings's terminology $(29$, p. 1 7$)$ is envolved. Gregariousness, however, adds the desire to be with those of one's kind.

The baby shows by a smile at the age of two months, according to Darwin (2 I, p. 289), Preyer (6o) and Perez (59, p. 29) that it enjoys the presence of others. This reveals gregariousness. O'Shea says: "When one sees an infant reciprocating 
the loving expressions of its mother, and later pleading with her to remain near by merely that he may enjoy her presence, it seems beyond question that he has brought with him the rudiment of sociable feeling which causes him to ascribe a social value to persons and to desire to have friendly intercourse with them" (58, p. 5). Referring to the work of Sully ( 78 , p. 242) and of Kirkpatrick (46, p. I 19) O'Shea continues: "It is not too much to say that there is a kind of pleasure in personal intercourse which the child experiences before he has completed even six months among us" (58, p. 5)". Cooley's statement on this point is as follows: "By the time the child is a year old the social feeling that at first is indistinguishable from senscious pleasure has been much specialized upon persons, and from that time onward to call it forth by reciprocation is the chief aim of his life" ( 18, p. 49). Kirkpatrick says: "As early as the second year they (children) manifest great pleasure in the company of other children near their own age" $(46$, p. Iig). McDougall says that "agoraphobia seems to result from the morbidly intense working of this instinct" (49, p. 85).

As the child grows, gregariousness becomes sublimated in various sentiments, one of the most important of which is 'active sympathy,' to use McDougall's terminology. This constitutes the second level in the development of sociability. Active sympathy is a different process from the crude, sympathetic reaction. "It involves a reciprocal relation between at least two persons; either party to the relation not only is apt to experience the emotions; he actively seeks the sympathy of the other, and, when he has communicated the emotion, he attains a peculiar satisfaction which greatly enhances his pleasure and his joy, or in the case of painful emotions, diminishes his pain" (49, p. 168). Crude sympathy is that which Darwin saw in the expression of his child "at six months and eleven days by his melancholy face, with the corners of his mouth well depressed, when his nurse pretended to cry" (2I, p. 294). When this crude sympathy is supplemented by gregariousness the product is the sentiment of active sympathy. We follow McDougall here: "Since man certainly inherits this (the gregarious) instinct, we may see in this the principle that we need for the explanation of the development of active sympathy from the crude sympathetic induction" (49, p. I 70).

Sympathy deals, however, only with the affective phase of experience. Sociability, on the other hand, presupposes ideational as well as emotional experience. Sympathy can scarcely be used to denote both types of process, since sympathy means suffering with, Mitgefühl. The broader meaning added by the process of intercommunication of thoughts is 
expressed by the term rapport, as this presupposes both the emotional and ideational intercommunication. Sociability, then, is the sentiment which finds its manifestation in satisfaction when two persons are en rapport, and in loneliness when this need for intercommunication of thought and emotion is unsatisfied.

As distinguished from gregariousness, sociability requires intercommunication of experience between individuals, reciprocity of thought and emotion, if not absolute free trade. One of the walls in the structure of sociability is the desire to be appreciated. This involves at least an awareness of personality, and it increases in direct ratio as the sense of self becomes more clearly defined. The longing to be appreciated is one of the most universal human cravings and its satisfaction is one of the chief functions of sociability. The complementary wall of this structure is the possession of the power to appreciate others. There can be no sociability without subordination of self to an extent necessary to allow of a recognition of other selves. Prof. James said: "We are not only gregarious animals, liking to be in sight of our fellows, but we have an innate propensity to get ourselves noticed, and noticed favorably by our kind. No more fiendish punishment could be devised, were such a thing physically possible, than that one should be turned loose in society and remain absolutely unnoticed by all the members thereof. If no one turned round when we entered, answered when we spoke or minded what we did, but if every person we met 'cut us dead,' and acted as if we were non-existing things, a kind of rage and impotent despair would swell up in us, from which the cruelest bodily tortures would be a relief; for these would make us feel that, however bad might be our plight, we had not sunk to such a depth as to be unworthy the attention of all" (43, p. 293-294). The ability to subordinate self involves the development of the sense of the alter. Baldwin (7) and James (43, p. 29I-40I) have shown that the sense of the alter is acquired with the sense of the self. This is no easy, acquisition, but comes only with years of knocking up against other people. The studies of group life have shown that as soon as the child is able to leave his mother's apron strings, at about five or seven, he seeks the companionship of others of his kind. Thus is gregariousness manifested. O'Shea says: "The boy at first wants to be it. Gradual discipline in group relations develops the group consciousness" (58, p. 304). The reason why early activity is unorganized, uncontinuous, inco-ordinate, is because the children have not yet learned to get out of themselves and see the game as others see it. A game of baseball among pubescents is a noisy, riotous, scrappy affair and it 
almost invariably terminates in a fight. The 'fighting instinct' here finds its raison d'être in modern society in serving the function of subordinating innocent, unsophisticated self-feeling to the will of the group. The gregarious impulse compels them to get together so again and again they try it, and gradually as the result of hard knocks, each learns to appreciate the rights of the others. In this way is laid the foundation of sociability, the power to appreciate the other fellow's point of view. This process usually takes until the age of twelve, as the studies of group activity have shown.

The negative evidence of sociability is lonesomeness, nostalgia. This feeling is manifest in all types of mental culture. It appears in its highest form among scientists, philosophers, artists, or other pioneers on the frontier of thought, when separated from minds sufficiently developed to appreciate their interests. Hauptmann in "Einsame Menschen" (38) gives the classical picture of this type of loneliness. Literature furnishes many examples; actual life many more. In Chap. XVI of the Epilogue of "War and Peace," Tolstoi presents a fine illustration of this highest type of sociability: "Natasha and her husband left alone, also talked as only wife and husband can talk, namely with extraordinary clearnessand swiftness, recognizing and communicating each other's thoughts, by a method contrary to all logic, without the aid of reasonings, syllogisms, and deductions, but with absolute freedom.

As in a vision everything is illusory, absurd, and incoherent, except the feeling which is the guide of the vision, so in this intercourse, so contrary to all the laws of logic, the phrases uttered were not logical and clear, while the feeling that guided them was" (82). The demand of sociability in the cultivated man is a burning desire to talk to some one about the problems that occupy the thoughts. To be sociable does not mean that individuals must think alike, or hold the same opinion, but that they must understand and appreciate each other's thoughts; they must be congenial in their thinking. This involves us in the subject of congeniality of interests, which is discussed in the following chapter.

For gregariousness, then, in Baldwin's schema we substitute sociability, a more highly developed sentiment, as the primary psychological factor of those which produce club organization. It is this which brings children together originally, and after clubs are formed it is sociability which of all forces is the most powerful in holding them together. By far the most prominent reason given by children for the existence of clubs is that they enjoy being together. Nor does the power of sociability

I dimirish with age, for with rising mental grasp rises also the type of sociability. In the boys' club sociability is satisfied. 
in the athletic contest, the interplay of physical experience; in adolescent clubs sociability utilizes to a greater extent the interplay of emotional experience and to a lesser degree of ideational experience. With adult clubs sociability is more dominantly satisfied with the interplay of ideas. In one level of society those ideas may constitute nothing but gossip, or the news of the more concrete, nearer interests. In the scientific or professional society this sentiment is satisfied by the food hardest to digest, but most tempting to the educated mind. Groos has recognized this where he says, in "The Play of Man" (3I, p. 337): "Finally, I remark that a playful motive is often discerned in the formation of the multifarious clubs for the advancement of some worthy object in this age of abounding culture. We all know persons for whom the absolute interest in the ostensible purpose of the club would be out of the question but for the good company. The mere fact of being one of a group is satisfaction enough to the gregarious instinct and the playfulness of this condition can scarcely be questioned." Hugh Black points out the fact that, "the very existence of the church as a body of believers is due to this necessity of our nature, which demands opportunity for the interchange of Christian sentiment" (10, p. 72). In all societies, this interaction of individuals upon other individuals as they impart their experience and receive in turn the experience of others, produces a satisfaction which is the chief cement binding clubs together.

The second factor of those which determine the establishment of the club is contagion. Baldwin speaks of this as a group of factors which he calls spontaneous or plastic, as we pointed out above. Tarde (8o) attempted to explain all social organization by this factor alone, which, while failing to recognize the other factors, has forced everyone to appreciate the immense rôle played by imitation. If Tarde had been treating preadolsecent clubs only, instead of the whole social organism, we might follow his position more closely. But imitation involves in its very definition something to imitate. The original model was formed to some degree through deliberation. So with clubs. Adult clubs form the model copied by children.

The studies show that with boys and girls under thirteen or fourteen the clubs are merely incidental to the other group activity. The club is just another form of play, i.e., is a form of activity carried on without an ulterior motive. A few examples illustrate the general rule that the form of organization as well as the content of the activity of preadolescent clubs is the result of contagion. 
"When I was about twelve years old, I became acquainted with a girl two years older than myself, who, as she was in high school, seemed a very great and marvelous person to me. As she lived near me, we naturally became friends, and although she treated me in a sort of supercilious manner such as girls of that age are apt to use toward younger ones, I admired her with all my heart, and looked upon all her words and actions as an example. One day I overheard her talking to a friend about some secret society to which she belonged, and of course I could rot rest until I found out all the particulars and had made plans for the forming of a secret society of my own. I told three other girls about it and they were all eager to be in it also. Our place of meeting was to be the darkest corner of our attic and the aim was to write a book of joint authorship that when published was to be the marvel of the age. (It was the latter, though I'm sorry to say it was never published.) The meetings were lighted by candle-light, and the password was: 'I have told no one.' The entire society consisted of six girls and a rag-doll, which was the mysterious seventh person; and each member brought one cent to each meeting, which occurred each Saturday afternoon. The business of the meeting was soon dispensed with, and then each week a member would write a new chapter to the book and read it, as her part in the programme. After the reading of the chapter refreshments were served which were six lollypops or peppermint sticks, bought with the dues of the week previous. This organization lasted for nearly a year, and then would not have become dissolved had not illness (in the form of measles) overtaken four of the principal members. The book certainly was on its way to be a masterpiece, but fate interfered, and the short, sweet life of the "Society of the Daughters of Literature' ended."

This account shows more individuality than most and, in that respect, shows less the force of contagion, yet this club was the result of suggestion.

As contagion almost entirely explains the form of organization of the club in the years of preadolescence, it is after that age and throughout adult life a very powerful factor. Deliberate organization always sets the type; the thousands of copies are run off from an electroplate. High school fraternities mimic the college organizations. The later college societies copy those first formed. The secret fraternal organizations which have a membership amounting in numbers to one eighth of the entire population of the country are not fifty years old. They are imitations in one form or another of the three earliest, which have had a history of many generations. New scientific societies are modeled entirely on the constitutions of older ones. The fact of contagion in determining the organization is so evident as to need no further elaboration.

The third great factor in this process of club formation is 3 deliberation. In an earlier paragraph reflective action was made synonymous with activity carried on for the sake of an end. Clubs, the organization of which are the result of deliberation from that fact imply that they have a purpose in mind. Another implication of deliberately formed clubs, or voluntary associations, as they may now be called, is that their members realize the importance of united action; recognize strength in
union. 
A classification of voluntary associations necessitates a recognition of all the motives that move men to united action. The classification of motives is a problem for the ethicist. Clubs might well be grouped under three headings: (I) those formed for self-advancement; (2) those formed for the advancement of others; and (3) those formed for the advancement of a cause. Most voluntary associations unite all these motives and it would be impossible to evaluate all organizations on this basis.

In our studies the deliberate motive did not make its appearance until the age of twelve to fourteen. Among the girls' clubs it was found that those clubs which were not merely incidental to the play life of the group did not appear until about fourteen. In Sheldon's study the group of literary, music, and art clubs was insignificant until fourteen. Among boys the growth of the deliberate motive is harder to trace. Johnson's study, "Rudimentary Society among Boys" (44) furnishes an excellent example of the way rules develop by the trial and error method. In the McDonough School, isolated several miles from Baltimore, these boys were comparatively free from suggestion. Having new situations to face they worked out original rules in regard to the gathering of nuts and eggs, catching rabbits and muskrats. A picture which more truly parallels the actual process of development, as it occurs in an unisolated situation, is that painted by Pres. Hall in "The Story of a Sand-Pile" (36). Gulick's study reviewed above, showed that co-operative games appear after the age of twelve. Such games require some degree of planning and forethought, though to a lesser degree than is required in a voluntary literary club, because all the boy's previous training has been in athletics. The beginning of the high school period is as early as deliberate motives play any great rôle either in boys' or girls' clubs.

In summary of our consideration of the dynamic mental factors involved in the formation of the club: All clubs are at base founded as the result of the innate tendency to be sociable. But the club may be formed either as the result of contagion or of reflection. In the experience of the individual it is formed first through contagion; later through deliberation. In the adult club both forces are at work.

\section{Chap. III. The Mental Conditions Necessary to the Formation of the Club}

In the preceding chapter the aim was to present all the mental forces which in their functioning produce the club. They are the seed; their fruit is the club; but the soil of human 
nature which is the environment in which their development occurs must needs be of a peculiar sort. There are certain conditions necessary to the formation of the club, which it is the purpose of this chapter to discuss.

The first condition is that there be individual differences in

1 the capacity of leadership. In group activity it is necessary that there be some one to take the initiative, to be the leader. There can be no united action where all are blind followers with none to suggest or guide. However, it seldom happens that any group assembles in which there is no one who possesses more ability as a leader than do the others. This is one of the commonest of individual differences. In children, as in adults some are leaders, a greater number are followers. Mumford has written a thesis on this subject. Groos says:

"The blind obedience accorded a leader of a little band is calculated to fill parents and teachers with envy. Here the social impulse is supreme in the demand for association and classification which governs and directs society. . . The common fighting plays of children markedly exhibit this voluntary submission to a leader, less known, I think, in regulation games than in the many contests which a crowd of children will naturally fall into when a few belligerent spirits are present; when there is a trick to be played on schoolmates or janitor, or an orchard to plunder, some unpopular person to annoy by breaking his windows or otherwise damaging his property-in these escapades the leader's word has absolute authority, and the most docile children will commit deeds in blind obedience which fil their parents with amazement and horror." (3r, pp. 338-39.)

The studies of clubs show the importance of leadership. Leadership is one of the most prominent characteristics of the gang, as shown particularly by Puffer's study. Leadership is less prominent in girls' than in boys' clubs. 'This is to be explained, probably, by the nature of the activities of the two sexes, or on the sexual differences which determine the activities. The physical activity of boys demands leadership; in sewing, serving tea and social activities there is less occasion for leadership. Most of the cases where officers existed in girls' clubs may be explained by contagion. One girl reported that there was no definite term of office, but new officers were elected whenever they felt the need of some excitement, thus the fact was revealed that in this case the election of officers was merely another play activity. Interesting in this connection is the comment of Groos:

"It seems that those manifestations of the social impulse relating to subordination are not pursued by women so energetically nor in the same way as by men. Woman is the guardian of good form, but as a rule she will not subordinate herself to rigorous law. I think any customs agent will bear me out in the statement from his observation of the behavior of travellers. This probably results from a difference in the instinctive equipment of the sexes; fighting impulses which are strongly developed in the males, further the social ones by reason of their imperative requirement of association. . . The success of American women in their 
movement for emancipation is largely furthered by their participation with men in various sports and the consequent better development of their social capacities (31, p.339-40).

The second condition necessary to the formation of the club is congeniality of interests. "The term interest," says Miss Calkins, "is best used as a synonym for involuntary attention" (15, p. 103); or as Dewey states it, interest "is impulse functioning with reference to an ideal of self-expression" $(23$, p. 22). The direction of one's interests is determined by temperament, that is, by inherited Anlagen, and by the type of experience lived through. Dewey says: "they (the occupations of the individual) decide the sets of objects and relations that are important, and therefore provide the content or material of attention, and the qualities that are interestingly significant"' $(24$, p. 220). The interests of young children are similar, since temperament is but dimly manifest until self-consciousness develops, and because early experience is approximately alike for all. The children of master and slave play together in perfect harmony. In later years social equality is impossible because of the disparity of interests. Similarity of experience or training, in individuals of similar native interests, tends to give approximately the same level of ability, the same level of apperceptive mass; ability to understand the same ideas, to appreciate the same art and literature and music, to carry on the same activities of work and play; opportunity to enjoy the same social status, to see about the same amount of the world, to mix with about the same class of people; in sum, to develop the same interests.

A club to be durable must be formed by people having the same type of interests. Women's clubs must consist of women of the same social stratum. There can be no working together, between the woman on the rag-time level of appreciation and the woman on the symphony level. A social club is unsuccessful in which some members know of nothing to converse but gossip, while others have broadly trained interests. Young boys and girls can't get along together in clubs because their interests are absolutely different. Miss Addams calls "the companionship of mutual interests is the soundest of social bonds" (4. p. 15 I). Ross says the labor union is due not to a spirit of association, but interlacing interests (65, p. r8I). Those who would work for unity of different religious denominations should not overlook this fact. It is by no means implied in this connection that the different members be of like minds; that is, agree in their points of view in regard to religion, politics or what not, but it does mean that they agree in having an interest in the ultimately true position in regard to these matters. It must needs follow, then, that they will be 
undogmatic enough to recognize the possibility that some other then their own viewpoint may be the right one. A very good club may be formed of Jews, Catholics, Protestants and atheists; they may meet on the basis of congeniality of interest if, back of their desire to support each his own view, there be a common interest in the truth.

Ratzelhofer considered interests to be the ultimate psychological factors which differentiate groups in society (62). He failed to recognize, however, the deeper underlying forces which develop individual interests. He over-emphasized native interests and underestimated the power of training. Moreover he was dealing with the larger groups which constitute society. Our position is, merely, that congeniality of interests forms one of the conditions of the successful club.

In the formation of clubs failure is often experienced, as in many other movements, the stated reason being that the time was not yet ripe. Translating this metaphor into a psychological statement, we would say: a sufficient number of people had not acquired the same particular interest. The history of the woman's club movement illustrates this. To use a specific case, the attempt at Seneca Falls, N. Y., in 1848 , to form a suffrage society, was a failure. The club could not get more than twenty members and only lasted about a year because as the organizer said: "Amongst my own sex I found too many on whom ages of repression had wrought their natural effect and whose ideas and aspirations were narrowed to the confines of 'woman's sphere,' beyond whose limits it was not only impious, but was infamous to tread." In other words they were not interested in this movement.

Consciously or unconsciously clubs recognize the necessity of congeniality of interests, and realize further that the more the congeniality the sounder is the foundation of the club. Observe the eligibility tests employed by the Daughters of the American Revolution and that type of society as a means of keeping out the undesirables. Social clubs require an extraordinary initiation fee because they want only such as have sufficient wealth to be interesed in the same general atmosphere of recreation and wine. The American Psychological Association requires of candidates that they be of a certain rank in the profession, in order that they may be confident that all members shall have a fundamental interest in the science. College societies, and especially fraternities, generally have a certain individuality. Men of the same type tend to get together. Students recognize this freshman as a typical Tau Delt man or cut out to be a Chresto. Occasionally misfits occur; a man gets into the wrong society. If there are several misfits in the same club the resultant conflict of interests 
causes hard feeling, disagreement, inability to co-operate and disruption.

These two psychological factors are necessary as conditions of the club's formation, viz., individual differences in the capacity of leadership, and congeniality of interests. No stable club can be formed unless some one at least of the club is a leader. Settlement workers and club directors learn to recognize this when in artificially grouping boys or girls, leaders have to be provided. Dr. Krackowizer describes two cases of clubs that applied for admission to the Boys' Club of the Oranges, and in both cases the club lasted but a week. The fact was that there were no recognized leaders in either group. The other necessary condition for club organization is congeniality of interests. When both of these conditions are present, and only in such cases is there a possibility of forming a club.

\section{Chap. III. Mental Forces Produced by the Club}

It is the province of this chapter to discuss the functional aspect of the club, to study the contribution of the club to mental life. Of those forces resulting from club organization, the one of most general significance is that known as the social stimulus. Although produced by the club it is not peculiar to it, but is in evidence in any group, whether or not the group is organized. The most accurate studies yet made of it are those with school children. Schmidt (72), Meumann (53), Mayer (52), Triplett (83) and others ( 13 and I4) have demonstrated that in all types of school work, except that requiring individuality, better results can be obtained of children in groups than separately. That this force is something different from the stimulus of competition or ambition is evident from the experience of the actor, singer or lecturer who can play his part better under the stimulus of an audience than with empty seats. The group itself exerts a favorable influence. The stimulus is increased when all the members of the group are performing the same task. This is illustrated by dancing, choral singing, marching in step, as Frederick demonstrated in his army, team work in games or work, shouting at a track meet, a ball game or political rally, paced work in the laboratory or a paced race on the track:

In the club this group stimulus is always present and of greater power than in unorganized groups. In the presence of the members of his own club a man is stimulated to accomplish feats and rise to supremer achievements than would be possible for him to reach in any other presence. Since this product of club organization is shared with every other type of 
social life it need be mentioned only incidentally. Of much greater significance are the other forces to be considered, viz., esprit de corps, honor and friendship.

Esprit de corps is a sociological form which needs to be translated into psychological processes. As Prof. James pointed out, in his chapter on the "Consciousness of Self:" "In its widest possible sense a man's self is a sum total of all that he calls his, not only his body and his psychic power, but his clothes and his house, his wife and children, his ancestors and friends, his reputation and works, his lands and horses, and yacht and bank-account." (43, p. 201.) The one phrase of this comprehensive self, of interest to us in this connection, is that which refers to the group of family and friends. The child acquires a peculiar sense of belonging to his immediate social group, and as his group enlarges, his sense of belonging widens. There is an attitude of satisfaction in the feeling of belonging to a family or to a community, which is often not recognized until one is isolated, relatives dear or estranged, and the community cold and unappreciative. It is the loneliness that arises when one feels that he does not belong to any particular group that in part explains why so many answers are received to advertisements of matrimonial bureaus.

This sense of belonging is the germ of Baldwin's "socius," which he defines as "the higher sense of commonalty, personal implication, mutual interest which social intercourse arouses in him. He (the boy) has a sense of the socius, for example, when his own school is brought into rivalry with the school around the corner" ( 7, p. 32). Later, Baldwin says: "The family esprit de corps has such a firm root in the breast of the individual that family action is as necessary to him as action in his own private interest." (7. p. 407.) Approaching the subject from a different viewpoint Prof. Ames said in an address at Minneapolis, Dec., I910:

\footnotetext{
"In more sustained associations such as the workmen in a factory experience, in daily contact, and co-operation, in their home life and neighborhood relations - there is built up a more elaborate and persistent class feeling. There is developed a more definite sense of the group, a feeling of loyalty to its members, of obedience to its standards and of devotion to its ideals. They recognize each other with a sense of kinship and exchange of confidence which they would not show toward men of another class. The same fellow-feeling springs up spontaneously in all men of the same trade or profession and among any companies or gangs whose work or fortunes bring them into mutual contact. Over and above their explicit acknowledgment or realization, there is present a powerful group spirit which has sprung up from their association."
}

Miss Addams points out that one of the most powerful forces pulling the boy to work at fourteen is, if the family purse is small, his loyalty and affection (3, p. 126). Elsewhere in 
this wonderfully expressive book, "The Spirit of Youth and the City Streets," she suggests that public games be extended to develop the unity of feeling that is aroused by our one national game (3, p. 96). In no situation is esprit de corps more easily aroused than in support of the home team.

A very suggestive treatment of esprit de corps is that of Cooley in his "Social Organization:"

"The result of intimate association, psychologically, is a certain fusion of individualities in a common whole, so that one's very self, for many purposes at least, is the common life and purpose of the group. It is always differentiated and usually a competitive unity, admitting of self-assertion and various appropriative passions; but these passions are socialized by sympathy, and come, or tend to come, under the discipline of a common spirit" (18, p. 23).

He reminds us of how boys will endure cruelty and injustice at the hands of their fellows, such for instance as hazing, rather than appeal from their fellows to their parents or teachers. In such cases the family esprit de corps is weaker than that of the student group.

Ross recognizes the same spirit when he writes: "The lively sense of a common life enables mates, kinsfolk, neighbors and comrades to love and understand one another, to yield to one another, and to observe their forbearance and good offices that make associate life a success. In such a case the group does not make the ties; the ties make the group" (65, p. 432).

All these quotations show that no matter what the cause or group of causes effecting the establishment of the group, when once established there is added a new cement to bind it together. Davis expresses it in the following way: "Ideas or sentiments, and also social institutions, when once in existence become thereafter psychic or social factors in all future reactions in essential independence of their origin or their original associations. . . . We see daily private societies formed for all sorts of special purposes, literary, charitable, artistic, political, what not. But an organization has hardly been constituted before it becomes an end as well as a means in the lives of those connected with it; and in that portion of society which it infiuences the association functions not only as a force for turning social agencies in a special direction beyond itself, but also in part for turning social energy to itself to be absorbed therein" $(22$, p. 207). It is stated more concretely by Lee: "And the team is not only an extension of the player's consciousness; it is a part of his personality. His participation has deepened from co-operation to membership. Not only is he now a part of the team, but the team is a part of him. Membership becomes a part of a man, an essential part of him, something which cannot be taken away without taking much-indeed 
the greater and more significant part-of the man's life with it" (48, p. 490).

Puffer's and Browne's studies show the strong part which loyalty to the group plays. Among many examples given by Browne, is found this: "Boy in D-'s gang stole some cherries. He was reported to the boarding school by the woman who owned the cherries. Her description tallied with that of $\mathrm{D}$-. He was whipped for the offender, although he was not the boy that did it; yet he did not tell on the guilty boy" (I2, p. 27I). We quoted in the section on gangs Robert Woods's description of loyalty to the gang, and how one boy of his acquaintance, though his family had moved to Dorchester, and he had outgrown the old gang in education, still made it his custom to return to the old corner on Sundays. The blood feud of the Kentucky mountains, the sympathetic strike, refusing to bet against your own college, or turning down the offer of a higher salaried professorship because of loyalty to the old schoolscores of illustrations could be piled up to show the working of esprit de corps; but these will suffice.

One particular element in esprit de corps, present in some more than in others is the feeling that one's own group is better than any other. One's own interest is always more important in his eyes, and more valuable, than that of any other. One's own club is better than any other. This is only a broadening of the positive self-feeling that manifests itself in the feeling that, after all, the things of my own life are of more value for me than are the things of any one else. This is the basal idea in the expression: 'number one first,' or in the instinct of self-preservation. Applied to the group, one of the manifestations of this spirit is in the clique. The differentiating element in this type of group spirit is the feeling of caste, or of exclusiveness and aloofness. This was found in many of the girls' clubs. From our data we cannot entirely agree with O'Shea's observation that: "Until adolescence the child seldom recognizes caste stratification" ( 58, p. I5). Continuing, he says that dress plays no part in the groupings of boys, and its rôle among girls up to the sixth or seventh grade, is of slight importance. With adolescence comes differentiation of groups on the basis of wealth. Sororities and fraternities grow in high school, or even in the seventh or eighth grade more among girls than among boys. This differentiation takes place more in the social activities than in the games and athletics. Our observation would be that the feeling of caste is present with preadolescents, but becomes stronger at puberty. . Sheldon found the expression of caste earlier than puberty. His conclusion was that the feeling of caste reached its culmination at about ten. "While its expression in the form of bullying 
and teasing, as might be supposed, is more intensive among boys, the feeling of exclusiveness and pride appears much stronger in girls. Girls, if so told by their mothers, think themselves too good to play with girls of the working classes or of alien nationalities. Boys, on the contrary, will often run away and disobey parental injunctions to get a chance to play football or baseball with boys of any nationality, Italians, Jews, Irish or even negroes" (67, p. 435-36). Our data do not uphold the conclusion that cast feeling culminates at ten, however, but that it grows more intense with age, at least until the end of the high school period, as observations of high school students show.

The statement made above is that the clique spirit is a broadening of positive self-feeling. The process would seem to be this: in the group activity the individual, originally selfcentered, by continual buffeting about by other self-centered children, gradually learns to recognize the rights of the others of his group. This process was described in detail above. After a while the children learn to do team work and there develops a feeling that their team is better than any other team; not necessarily that they can play better, but they are better. The native tendency of each individual to regard himself as of more value than others, which is the root of the caste spirit, becomes ascribed to the group, with the result that the individual's own group becomes more valuable in his eyes than any other. The growth of the caste spirit parallels that of co-operative play, which becomes well established by puberty.

The general observation is that the caste spirit is stronger in girls than in boys. May not the explanation be, that, whether or not the girl of to-day is born with that diathesis, woman's experience has been such as to develop the caste spirit in her to a higher degree than man's experience has in him? Through group activity boys and girls alike develop a feeling of superiority as respects their own group. Boys' groups, however, compete constantly with other groups, and the process that went on earlier between individuals now transpires between groups, and a feeling of superiority is developed for a still broader group. Team spirit develops into school spirit, and the spirit of loyalty to, and assumption of superiority to the school, is greater than that to the class. This experience is not generally true of girls. Their loyalty to, and ascription of superiority to their set, remains much stronger than that of boys, and the accompanying fact is that the girls' set has little opportunity to compete with and be defeated by other sets. It has been the writer's experience in a co-educational college that the girls support their class basket ball team as loyally as do the men, but that it is harder 
for them to co-operate with their erstwhile opponents to compete against another school than it is for the boys. An incidentally concomitant fact is that girls take defeat harder than do boys. Many other manifestations of this phenomenon might be cited, such as woman's greater family pride, interest in genealogy and the like. Unless by competition with other groups our group becomes disillusioned, this spirit of superiority acquires a very narrow character and a clique is formed. Girls rise to the level of loyalty to a small group and tend to remain on that level, because of lack of competition between groups, while boys get over their clannishness by competition with other groups.

The relationship of the clique spirit to esprit de corps is thus evident. Esprit de corps is a sentiment that does not exist until the group is formed, but it appears with the group and is one of the strongest forces holding the group together.

Another psychic force peculiar to the group, and of particular importance as a product of club organization, is honor. Simmel shows the intermediacy of honor between morality and criminal law as a determinant of conduct. Morality is the personal standard of behavior; criminal law is that standard required as a minimum by the state. The code of honor is set by the small social group and is different for different groups $(69$, p. 68o-82). The more firmly established the group and the more individual its character, the stronger is the hold it has upon the conduct of its members.

There is a close relationship between esprit de corps and honor. In intensity the correlation is direct. The stronger the feeling of attachment the individual has for the group, the more is he bound to conduct himself in accordance with the code of the group. In clubs of long standing, such as the Masonic.Order, the code of honor is often of greater strength than is that of morality, when, for example, lodge brothers are shielded from punishment for infractions of law. It is not generally the rule, however, that honor and morality are antagonistic; they usually supplement and reinforce each other. One of the most common features of honor among clubs is this rule which demands that fellow members be assisted in times of adversity, sickness or death in the family, be supported when running for office in the community, be defended from calumny and, as in the case cited above, be shielded from justice. It is not honorable to 'snitch,' or inform the authorities, when one of the gang has done wrong. The gang have their own standards of conduct which concern the essential features of their mutual relationships, and to transcend one of these rules is often to lose membership in the gang. So it is with the 'honor of a gentleman.' To fail in any of its tenets 
is to lose caste in that fraternity. In some sections of the country the esprit de corps of the group of 'gentlemen' is as strong as that of a sworn brotherhood. Professional honor is particularly strong among physicians. Through this unwritten code incompetent physicians who, because of their ignorance, carelessness or lack of skill, fail to save the lives of their patients, are allowed to continue practicing because no one of their gild will expose them. Another point in their code is the rule of secrecy regarding disease which permits undesirable marriages. In the profession of law the code of honor is formulated in written rules. It is acknowledged by this code that a lawyer may undertake with propriety the defense of a person accused of crime, although he knows or believes him guilty. As an individual member of society governed by the standards of morality the lawyer believes this guilty man should be punished; as a lawyer, governed by the standards of honor in his profession, he is bound to exert himself to the utmost to prevent the fulfillment of justice. So each well organized club and each well defined social group has its code of honor. Reacting upon the club the effect of honor is to strengthen the ties that bind it together; as to its influence upon the social organism as a whole we need not here lay emphasis. Few moralists, however, have recognized how large that influence is in determining conduct.

Another factor, the effect of which is to solidify the once formed group, is friendship. To be sure, in children's clubs a condition of friendship exists before the club is formed. This is not always the case with adults. When such a group forms a club, friendship arises as a result of association in a common task. Jones has called this emotion the feeling of attachment (45, p. 6o-79), which is another expression for the feeling of belonging, which was made the basal element in esprit de corps. This sociological mode and that of friendship have the same psychological foundation. As Cooley puts it: "Group sentiment, in so far as it is aroused by definite images, is only a variety of personal sentiment" (18, p. 79). Being admitted to a club arouses a feeling of attachment for the group; in a similar way, though to a more intense degree, being admitted to the confidence of another person arouses a feeling of attachment. Jane Addams says that: "no two persons, nor group of persons can come into affectionate relationship with each other unless they carry on together a mutual task" (4, p. 27I).

The origin of personal affection is to be found in the relationship of mother and child, as Sutherland has proved with a wealth of data (79). Love is developed through service. Ribot states it in this way: "It is an observed fact that a man attaches himself to another in proportion to the service he renders, 
rather than to those he receives from him" $(63$, p. 294). However the feeling of attachment may arise, its intensification is accomplished by the same process the race experienced, namely in service. Service has another effect, moreover, which it is important to consider in this connection. The mental process of doing things for another person develops not only a feeling of attachment for that person, but a subordination of self to that person. So also when one works for a group or for a cause. Thus friendship and esprit de corps each presuppose an Einstellung that is characterized by unselfishness. It therefore becomes made more evident that these two forces do have a powerful influence in the preservation of the club. These mental processes are the sine qua non of co-operation.

In this connection the relationship of chumship (if we may be permitted to coin the term) and the club is en rapport. Bonser's study of this type of friendship showed that chumming begins before four years; with girls the age of greatest frequency is six; with boys the curve rises more slowly, reaching its apex at ten. These friendships, as a rule, continue unbroken at least until the latter high school years, which was the age of the boys and girls when they reported. This shows that the feeling of attachment for individuals appears earlier than for institutions or groups. There appears to be no conflict between the institutions of chumship and the club. Bonser found the existence of chumships almost universal. The great majority of children also belong to clubs. The general situation would appear to be as it is described by one reporter: "Every girl has her special friend, some one to whom she tells everything. They can have fine times together, but if they belong to a club and make friends with the other girls, they have many friends besides each other."

\section{Chap. IV. Other Mental Forces which Aid the Continuation of the Club}

Aside from those dynamic processes which produce the club, and aside from the forces which owe their existence to the club, there are other forces which, if present, favor the continu$\checkmark$ ation of the club's life, viz., those that appeal to fundamental human needs, furnish expression to native impulses or satisfy instincts. The discussion of the more important of these forces, as employed by the club, is the task of this chapter; love of the mysterious, the satisfaction of positive self-feeling, acquisitiveness and curiosity by secrecy and ritualism; satiating the desire to realize the ideal through the dramatic features; satisfaction of religious and altruistic tendencies in philanthropic and religious activities; fulfilling 
the demands for recreation and physical exercise through athletics, sports and games of chance and skill; and answering these and other needs by the flamboyancy of big titles, benevolence and life insurance, literary, art and musical features. Clubs may consciously aim to satisfy these needs or may do so incidentally; they may plan deliberately to accomplish these ends, or they may accept these features as the force of contagion. Again the same activity may satisfy different needs in different individuals or groups. Secrecy, for instance, plays a distinctly different rôle in the fraternal order to-day than it played in the heretical sects of the Reformation. The need of protection, moreover, is more fully satisfied by secrecy in the Camorra or any anti-social organization to-day than it is in the Masonic Order.

For the sake of clearness it will prove more effective to centre the discussion about the different activities and practices of clubs than to discuss the different instinctive tendencies separately. The first of these to be treated is secrecy. Historically the principal rôle of secrecy has been the provision of protection to the members of an order joined together for some motive opposed by the powers, or by some power strong enough to be given attention. In modern society some of the best examples are given by the secret societies organized for the purpose of discussing heretical beliefs about religion, politics, philosopy and science, such as Der Palmbaum, the Anabaptists, Waldensians and the orders of the Illuminati ( 7 and 37). In America to-day there is no need of secrecy in order to avoid suppression of religious, political or intellectual societies. The anti-social clubs of thieves, pickpockets, tramps and other outlaws are the only organizations in which this human need is supplied by secrecy. Criminology furnishes a great variety of usages of secrecy as a means of protection. Havelock Ellis gives illustrations of the type of slang or argot used, which is peculiar to their class, and entirely unintelligible to any but those in the bond $(25, p .161-69)$. Gross in his Kriminal-Psychologie refers to the use of sprachliche Missverständniss, a use of language in such a way that the hearer knows that the meaning is something other than that spoken, and the speaker knows that the hearer will understand him as meaning something different than what is said $(33$, p. 383$)$.

The Handbook of Criminal Investigation (32) describes the disguises, false names, pretended illnesses, signs and signals, slang, ciphers, secret writings and graphic signs, used by criminals and tramps.

But secrecy is still a very prominent element in many of our clubs, among both adults and children. This suggests that it serves other needs than protection. One of these which it 
feeds is positive self-feeling. On this point, Simmel, who has given us the best discussion of the sociology of secrecy, says: "There is separation from others because there is unwillingness to give oneself a character common with that of others, because there is a desire to signal one's superiority as compared with these others. . . As a consequence of the fact that those who want to distinguish themselves enter into combination, there results an aristocracy which strengthens and, so to speak, expands the self-consciousness of the individuals through the weight of their own sum. . . We may observe, even in school classes, how small, closely attached groups of comrades, through the mere formal fact that they form a special group, come to consider themselves an élite, compared with the rest who are unorganized; while the latter, by their enmity and jealousy, involuntarily recognize that higher value. In these cases secrecy and pretense of secrecy (Geheimnistnerei) are means of building higher the wall of separation, and therein a reinforcement of the aristocratic nature of the group" (76, p. 486-87). Simmel would give a different account of the development of the clique than seems to us to be its genetic history, but his emphasis of secrecy is very patent. An illustration of what Simmel describes is provided in this description of a ten year old girl's club: "We were very select and had many secrets which we were sure to mention when there was any one around whom we wanted to make jealous." That is, positive self-feeling, in the form of a feeling of superiority is satisfied. But this reveals the fact that the secret has intrinsic value, which fact introduces another element.

Acquisitiveness, or the desire to possess, is tickled by the possession of a secret. To have a secret is to have something some one else wants and therefore it is of some worth. Sometimes the whole value of a secret is the fact that those outside the compact do not know it and want to. That is, curiosity is aroused, and anything that arouses curiosity is of value, as the proprietors of dime museums and side-shows well know. 'The people like to be fooled;' that is, they know that they will be made to feel foolish, but their curiosity is so strong they cannot resist the temptation to satisfy it. Children unconsciously recognize this when they invent sign languages, peculiar gestures of the hands, carry on nonsense gibberish and unintelligible whisperings. An instance of this kind was recorded above.

To answer the question: why does the secret arouse curiosity? is to disclose the primary source of value, namely the love of the mysterious. As shown by the mystic in religious, by spiritism, telepathy, slight of hand and conjuring, the mask ball and ghost stories and fairy tales, the love of the mysteri- 
ous is a strong motive power. It is this which furnishes the energy which runs most of the machinery of secrecy. As it works out, it involves other fundamental tendencies; first, curiosity, which becomes involved in acquisitiveness, and this in positive self-feeling.

The different stages of this process are illustrated by these examples: The illustration referred to above shows the love of the mysterious. This report shows the value of it in holding the club together. "The first club to which I belonged was composed of five little girls. Each member wore a badge of blue and yellow ribbon. It was a secret society. We met in the afternoon after school and just had a good time enjoying games and other amusements. This club only lasted three weeks because some of its members, who were six and seven years of age, made the secret known to the public in general." In many cases the content of the secret is of no importance. The first thing to appear is the fact of the secret; afterwards the secret acquires content. The that is at first of more importance than the what. This is illustrated in a club of girls nine and ten years of age. "About six or seven of us who always played together wanted to have a secret. This part was voluntary, but we could n't think of a nice enough secret, so one of our mothers suggested that we should always be good friends. The rest was all voluntary such as wearing little bows and having parties. I think this lasted about a year." The same condition is very nearly paralleled in the adult organization. Joseph C. Root founded and wrote the ritual for two absolutely distinct secret societies, the Modern Woodmen of America and the Woodmen of the World, and was also a member of the Odd Fellows, the Knights of Pythias, the United Workmen, the American Legion of Honor, and was a thirty-second degree Scottish Rite Mason. It is quite evident that the content of the ritual is of less importance than the fact that there is one. The ritual is a secret, the possession of which makes the order richer in its assets. Freemasonry itself owes not a little of its prestige to the profoundness of its secrecy. Yet in progressive Masonry the roll of membership, its purposes and acts are public property; silence is required solely in regard to its sacred rites. The same thing is true of student societies. Sudermann in the drama, "Der Sturmgeselle Socrates," tells a fine story of a group of men who continue in their old age to get immense satisfaction out of a secret society formed during their student days. Then there was reason for the secrecy; now it is absolutely unnecessary, and yet it constitutes the chief raison d'être of the club. Stevens describes over thirty occult, hermetic, theosophic or religious brotherhoods in which the love of the mysterious plays the most important rôle $(76)$. The very naming of college societies feeds the love of mystery, as illustrated by the Greek letters, the 'Skull and Bones' and 'Scroll and Key.'

The next step in development in the usage of secrecy is taken when it becomes used to satisfy acquisitiveness.

This is illustrated in its primitiveness by the following:

"When I was about nine years old, five girls and myself formed a club. It was known as the Contrary Girls Club, or C. G. C. Our main object was to get as many secrets as we could during the week, and then on Saturday afternoon we would meet and tell our secrets. The ones we considered the most important we would give some certain initial or initials, and then record them in a book."

It is then but a step from this stage to that characterized by the aristocratic feeling, the latter being the feeling of being better than the other fellow, the former being the desire 
to possess. The former is therefore the servant of the latter, since in our society rank is correlative with possession. The desire to possess something of value, be it nothing more than a secret, may thus be in motivation subordinate to the desire to rise in social rank. This is illustrated in student fraternities. Not their only feature, to be sure, and in the published intention not at all present, are those two motives. But in actual practise it works that way. The fact that a society is secret makes it stand out prominently in the foreground of the desirable social states. And this prominence encourages aristocracy. When the experience of the individuals thus raised into prominence has been broad enough to have toned down their primeval feeling of superiority, both in regard to themselves and to their group, the effect is good; if, on the other hand, this rise into prominence be made by less mature or less experienced minds, the effect on their view of the world is detrimental. The former is the aristocracy which should be emulated, the evolution of a group to a higher cultural plane; the latter is the false aristocracy which exhibits itself in snobbishness, bigheadedness and in extreme cases, megalomania. We find here the psychological reason why fraternities are detrimental in high schools. Boys and girls are too young, as a rule, to be able to experience the feeling of superiority, engendered by the prominent position which is the result of secrecy. This prominence, too, is extraordinarily increased because the other students are of the same age as the members of the fraternity, and their envy of the members of the secret organization is stronger than it would be at any other period of life. The same snobbishness, however, is produced by victory in athletics. Where fraternities exist the condition is made worse because of the fact that the man placed in an enviable position through athletic prowess is the most desirable candidate for the fraternity, and the cumulative resultant is a snob of the choicest variety, unless he be equaled by the snob of newly acquired wealth. Approximately the same importance is given to athletics and social life in college as in high school, but the effect in college is much less aggravating, because of the greater maturity of the students. The high school boy, who has been the easy victor in all contests, on entering college learns that there are others just as fleet, just as clever, and in all probability a few who are even brighter. A few defeats cures his youthful self-regard. In adult life, entrance into a secret order does not, as a rule, produce this deleterious effect of the high school age, because men are then old enough to be able to experience prominence without becoming conceited, and also because the prominence is less, on account of the ease with which men can become members of secret orders. 
It should be mentioned that while the prominence of secrecy in children's societies is due to these fundamental human needs which are satisfied, the form that secrecy takes is due largely to contagion. By far the greater part of the secret features here found are the result of imitation. Many have secret names, passwords, rituals, secret signs and other mysteries as a result of the fact that they know adult clubs have them.

Dramatic Features. Closely allied with the secret elements of the club are the dramatic features. By the dramatic features we mean all those attributes which appeal to the love of the make-believe. We need not delay to emphasize the fact that the pleasure in the make-believe, whether the subject takes part in the acting, or merely witnesses the acting of others, is an universal one. Miss Addams points out in a charming way the place this craving holds in adolescence, and that the reason why it is so exceedingly strong among the workers of the city is that the drama provides a transition between the romantic conceptions which they vainly struggle to keep intact and life's cruelties and trivialities which they refuse to admit. The satisfaction of the make-believe in the form of reading and reverie is denied them. But on the stage the youth can witness the deeds of his hero presented before his eyes; these he views simply as a forecast of his own future. This fascinating view of his own career it is which draws the boy to shows of all kinds (3).

The club to some extent satisfies this need. It provides a great hierarchy of offices and degrees.

Europe has its pageantry and titled nobility, its Order of the Bath and Garter, the Legion of Honor and Iron Cross. Americans satisfy this underlying human need by parades of Knights Templars, Elks and Odd Fellows, in which thousands put on sword and silk and scarf. They create for themselves such titles as Official Potentate, Imperial Deputy Potentate, Imperial Chief Rabban, Imperial High Priest and Prophet, Imperial Oriental Guide, Imperial First Ceremonial Master, as in the Nobles of the Mystic Shrine; the Grand Exalted Ruler, High Chief Ranger, Keeper of the Exchequer, Grand Almoner, or, as in the Imperial Order of Red Men, the Grand Incohoner, Great Senior Sagamore and Great Keeper of the Wampum. These titles, representative of hundreds, are well ridiculed in the following offices: Cock of the Walk, Bantam Cock, Chief Scratcher, and Early Bird, in the Order of Red Roosters, and Most Loyal Gander, Grand Custodian of the Goslings, Supervisor of the Flock, Grand Guardian of the Pond, and Grand Wielder of the Goose Quill, in the Order of the Red Goose. The love of the make-believe underlies the organization of the Concatenated Order of Hoo Hoo, the Prudential Patriarchs of Pompeii, the Knights and Ladies of the Golden Star and many others that might be mentioned.

Examination of the rituals, based on secret and secular themes, such as the story of the cross, building of the temple, David and Jonathan, Joseph, the Maccabees, Ben Hur, facts of United States history, nomad life, the friendship of Damon and Pythias and the crusades are used to increase both 
the mysterious and the dramatic elements in the club organization. Commenting on the ritual, Simmel says: "Every such society (a secret society with a ritual) contains a measure of freedom, which is not really provided for in the structure of the surrounding society. Whether the secret society, like the Vehme complements the inadequate judicature of the political area; or whether, as in the case of conspiracies or criminal bands, it is an uprising against the law of that area; or whether, as in the case of the 'mysteries,' they hold themselves outside of the commands and prohibitions of the greater area-in either case the apartness (Heraussonderung) which characterizes the secret society has the tone of a freedom "(70, p. 483). In other words, the secret society with its ritual transcends the humdrum, hard and fast facts of everyday life, and forces open the gates into the realm of the ideal, the world of the imaginative, the make-believe. Read over the names of the degrees in Scottish rite Freemasonry, from the highest level of Sovereign Grand Inspector General down through the thirty-three stata, some of which are, Sublime Prince of the Royal Secret, Grand Elect Knight Kadosch, Knight of the Brazen Serpent, Patriarch Noachite, Knight of the Rose Croix, Prince of Jerusalem and Grand Elect Perfect and Sublime Mason.

Forbush recognized this need, when he organized the Knights of King Arthur for boys, with their round table, their formality, ritual and titled officialdom (26). Consciously or unconsciously the Boy Scouts recognize it in their provision for hero-worhip, for playing at Indian life, at military drill and first aid to the injured. These activities satisfy the 'dramatic instinct.' Labor unions have introduced many of the features of the secret brotherhoods, such as 'riding the goat,' high sounding titles ritual, passwords, etc. Their fundamental purpose certainly has no connection with satisfying the dramatic instinct. In actual practise it is found that those unions are most successful which minister most widely to the needs of its members. Among these is the demand of the dramatic instinct.

Walter B. Hill calls the institution of the club the great American safety-valve (39). The teaching of our public schools is that any man may become president, when as a matter of fact they can't all be presidents. Hill says: "I made a test case of a small town, and found that every man, woman, and child (above ten years of age) in the place held an office-with the exception of a few scores of flabby jelly-fish characters, whose lack of ambition or enterprise removes them from consideration as elements of the problem. . . Here then we have the great American safety-valve-we are a nation of presidents." Holding office satisfies the love of the makebelieve, and incidentally, as other drama does, it trains for the real.

Besides these indirect ministrations to the call of the makebelieve, it is directly satisfied in all sorts of clubs by participation in the presentation of drama, readings and entertainments. By these dramatic features clubs increase their influence and perpetuate their life.

Other Features. The quotation from Mr. Hill introduces us to another set of factors used by the club. Holding office not only satisfies the dramatic impulse, but it is a sort of subtle 
flattery; it gives a realization of greatness, through cajoling positive self-feeling. The more flamboyant the titles, the more the feeling of superiority is tickled. This is not identical with the love of the make-believe, as is shown by the fact that there is satisfaction in playing the villain. Other means of adding to the satisfaction of this self-centered feeling are the addition of those agencies which actually do improve the individual status, financially, socially, intellectually, morally, etc. The beneficiary and insurance features directly improve financial status. Membership in fraternal orders, as well as in religious and social clubs, is oftentimes sought purely to improve one's business connections. Social status is acquired by the same means. And here we class the purely social clubs. Self-improvement is made a strong motive for joining the club, by its provision of education specifically in literature, art, drama, music and physical culture, and more generally in every subject of interest through the intercourse of conversation, discussion and set lectures. Thus the club aids the individual to gain a living, to improve his social status and to raise his general efficiency.

It might be a matter of debate whether the religious and altruistic elements in clubs should be classed with those in the preceding paragraph, or whether they should be treated as satisfying an impulse, distinct from that of positive selffeeling. We will not argue that point. The fact remains that the club does in many ways satisfy the needs expressed by these feelings. The religious and philanthropic societies do this directly; the fraternal societies have many religious elements, for instance the Masons, the Knights of Malta, and the Odd Fellows, whose motto is 'Friendship, Love and Faith.' Another feature of the club, about which there is similar difficulty of classification is the recreative, the provision of muscular exercise, mental relaxation, and games of chance or skill. The characteristic of this group of activities is the hygienic element. The result is self-improvement, yet the feeling satisfied is different in each case. Here, too, there are clubs formed entirely for athletics, as there are found those primarily altruistic and social. Every club which has a building or grounds of its own aims to satisfy this type of need.

But the club also satisfies at least one other instinct. Constructiveness is well fed in the activities of such men as Root, Clendenen, Upchurch, and the other organizers and ritual writers. There must glow in the breast of these constructive geniuses some such fire as Pres. Hall ascribes to the novitiate into the class of contributors to science after the production of his doctor's thesis. There is surely a peculiar joy that comes from the successful formation of a new organization, and a 
great many thousands have had the privilege of being charter members of clubs of all kinds in the last few decades.

- Another force unconsciously employed by the club, which has the effect of strengthening the group spirit, is that of opposition and conflict.

Struggle is a stimulus to growth. The mind, like the body, needs continual peripheral stimulation to keep awake. One of the chief services of the school examination is that it is a continual spur, keeping one at the height of working capacity. It brings the realization of the possibility of failure, and the desire to succeed and excel makes a conflict, a game, a contest of study, with big obstacles to overcome. Similar is the effect produced by the effort to attain some definite end, whatever be its nature. To have a purpose, whether it be to build up a business, to support a family and raise children, to excel in the profession, to have a real work to do gives zest to life and increases efficiency. This much is true of opposition in its effect on the individual.

Opposition to a group from without has a similar effect. Persecution always strengthens the ties between those oppressed. Minor differences are overlooked in the light of the greater need which cries out for unity. Some families can only be united by sorrow in the death of one of their number, or by some other great calamity, such as a scandal, when, as with political opponents, there is unity in the face of foreign war. External opposition has the effect of throwing into relief the stronger esprit de corps.

This is clearly seen with fraternities, particularly those among high school students. The feeling of unity among the members is only magnified by the fact that they have a common enemy who would destroy their club. Persecution of a religious sect strengthens it, unless it be strong enough to annihilate it, not merely because opposition gives more meaning to the religion, but also because it draws the members into closer fellowship.

A different psychic process is involved when there is antagonism between the members of the group. If this is too strong the group is broken up. But in moderate degrees it has the effect of strengthening it by providing what Simmel calls "one of those contrast-stimuli evidently demanded by the innermost needs of the unifying social bond, because there, as elsewhere, the permanent can emerge and come to conscious force only as a function of the changeable" $(69$, p. 48). This is as true of the social bonds existing between individuals as those binding large numbers. Periods of quarrel and disagreement seem to be a regular experience of lovers and of married couples. These estrangements are followed by reac- 
tions when the bond of unity is stronger than before the quarrel, the effect of the quarrel being to bring into consciousness the realization of the misery which would ensue if the bond were permanently broken, against which dark background is thrown the bright picture of the happiness which characterizes their union. The psychic process appears to be the same with the members of a club. Difference of opinion regarding policies is necessary for the purpose of making definite the real object of the organization. The club would die of stagnation, as many churches in fact do, were there no differences between its members.

\section{General Summary}

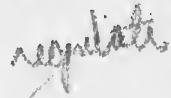

The description of the psychological elements utilized by the club has involved at least the mention of most of the social qualities possessed by man. The club in present day America is indeed a broad institution. Its broadest foundation is laid in sociability. Whether or not other sentiments are involved, this is always present. Unsociable individuals never form clubs. Soclability is therefore the most fundamental of all the forces which produce the club. It may be supplemented either by contagion or deliberation or both. Either combination will produce the club. Other forces may assist, such, for instance, as the feeling of personal attachment between individuals, but this is not essential. These being the forces, there are certain conditions necessary before their functioning will produce the club, those conditions being individual differences in the capacity for leadership and congeniality of interests. The club being organized begets other psychic forces of which we have discussed the social stimulus, esprit de corps, honor, and friendship. Besides these forces, clubs, either by their nature, or unconsciously, employ other factors which, by appealing to native tendencies, strengthen the club; such factors as secrecy, ritualism and dramatic features, agencies for self-advancement, financially, in status and in efficiency, religious and altruistic features, the provision of possibilities of recreation, athletics, games and amusements, and the force of opposition. Though the aim of this paper has been to make a contribution to the science of social psychology, it is hoped that, if the conclusions herein reached be valid, they may be of some suggestiveness to all who are interested in the formation of clubs, whether formed by any group for their own ends, or by adults for boys and girls.

\section{BIBLIOGRAPHY}

1. Addams, Jane. Democracy and Social Ethics. Macmillan, N. Y., $1907,277 \mathrm{p}$.

2. Newer Ideals of Peace. Macmillan, N. Y., 1907, 437 p. 
3. Addams, Jane. The Spirit of Youth and the City Streets. Macmillan, N. Y., 1909, 162 p.

4. Twenty Years at Hull-house. Macmillan, N. Y., I9 10, $462 \mathrm{p}$.

5. Aldrich, T. B. The Story of a Bad Boy. Houghton, Boston, 1897 , 26r p.

-6. BAIRD, W. R. Baird's Manual of American College Fraternities. Alcolm, N. Y., 1907, 574 p.

7. BALDwIn, J. M. Social and Ethical Interpretations of Mental Development. Macmillan, N. Y., 1897, 606 p.

8. - The Individual and Society. Badger, Boston, I9I I,

9. 2 Io p. The Basis of Social Solidarity. Am. Jour. Sociol., r9ro, vol. 15, pp. 81 7-31.

ro. Brack, Hugh. Friendship. Revell, N. Y., 1898, 237 p.

II. BoNSER, F. G. Chums; a study in youthful friendships. Ped. Sem., 1902, vol. 9, pp. 22 I-37.

12. Browne, T. J. Clan or Gang Instinct in Boys. Association Sem., I 900, vol. 9, 65 p.

13. Burnham, W. H. The Group as a Stimulus to Mental Activity. Science, $N$. S., 1910, vol. 31, pp. 761-67.

14. - - The Hygiene of Home Study. Ped Sem., 1905, vol. I2, pp. 213-30.

15. Calkins, M. W. A First Book in Psychology. Macmillan, N. Y., I9I0, 4I9 p.

r6. Carnegie Institution of Washington. Handbook of Learned Societies and Institutions. 1908, $592 \mathrm{p}$.

17. ConRadi, EDward. Academies and Learned Societies in Early Times. Ped. Sem., 1905, vol. 12, pp. 384-427.

I8. Cooley, C. H. Human Nature and the Social Order. Scribner's, N. Y., 1902, 413 p.

19. - Social Organization. Scribner's, N. Y., 1909, 426 p.

20. Culin, STEwart. Street Games in Brooklyn, N. Y. Jour. of Am. Folk-Lore 1891, vol. 4, pp. $221-37$.

21. Darwin, Chas. Biographical Sketch of an Infant. Mind, O. S., I877, vol. 2, pp. 285-94.

22. Davis, M. M. Psychological Interpretations of Society. Longmans, N. Y., 1909, $260 \mathrm{p}$.

23. DEWEY, JoHN. Interest as Related to Will. 2nd Supplement to the Herbart Yearbook for 1895, Chicago, 34 p.

24. - Interpretation of Savage Mind. Psych. Rev., 1902, vol. 9, pp. 2 I 7-30.

25. Elilis, Havelock. The Criminal. Scribner's, N. Y., I89o, 327 p.

16. Forbush, W. B. The Boy Problem. Pilgrim Press, Boston, 1907, $210 \mathrm{p}$.

17. - - The Social Pedagogy of Boyhood. Ped. Sem., 1900, vol. 7. pp. $307-46$.

28. Galton, Francis. Inquiries into Human Faculty. Macmillan, London, $1883,387 \mathrm{p}$.

29. Grddings, F. H. The Principles of Sociology. Macmillan, N. Y., I909, $476 \mathrm{p}$.

30. Grllin, J. L. A Contribution to the Sociology of Sects. Am. Jour. Sociol., 1910, vol. 16, pp. 236-53.

31. Groos, Carl. The Play of Man. Appleton, N. Y., 1901, 412 p.

32. Gross, Hans. Criminal Investigation. A Practical Handbook. Specialist Press, London, 1907, 889 p.

33. - Kriminal-Psychologie. Vogel, Leipzig, 1905, 701 p.

34. Gulick, L. H. Psychological, Pedagogical and Religious Aspects of Group Games. Ped. Sem., 1899, vol. 6, pp. I35-5 I. 
35. HALL, G. S. Adolescence. Appleton, N. Y., I907, 2 vols.

36. - The Story of a Sand-Pile. Scribner's Mag., 1888, vol. 3 pp. 690-95.

37. HaRTson, L. D. A Study of Voluntary Associations, Educational and Social, in Europe During the Period Iroo-1 700. Ped. Sem., I9I I, vol. I8, pp. 10-31.

38. Hauptmann, G. Lonely Lives, A Drama. Heinemann, London, 1898, $179 \mathrm{p}$.

39. HiLl, W. B. The Great American Safety Valve. Century, 1892, vol. 22, pp. $383-84$.

40. Holi,ANDER, J. H. and BarnetT, G. E. Studies in American Trade Unionism. Holt, N. Y., 1906, 380 p.

41. Howel, S, W. D. A Boys' Town. Harper, N. Y.

42. Hurron, L. A Boy I Knew and Three Dogs. Harper, N. Y., I 898.

43. James, William. The Principles of Psychology. Holt, N. Y., 1890, 2 vols.

44. Johnson, J. H. Rudimentary Society Among Boys. Hopkins Studies in Hist. and Pol. Sci. Baltimore, 2nd series, 1884, 51 p.

45. Jones, J. W. L. Sociality and Sympathy. Psych. Rev. Supplements, 1903, vol. 5, no. 18, 91 p.

46. KIRKPATRICK, E. A. Fundamentals of Child Study. Macmillan, N. Y., 1907,384 p.

47. Kropotkin, P. Mutual Aid a Factor of Evolution. Heinemann, London, 1902, $348 \mathrm{p}$.

48. LEE, Joseph. Play as a School of the Citizen. Char., 1907, vol. 18, pp. 486-9I.

49. McDougal, Wm. An Introduction to Social Psychology. Methuen, London, 1908, $355 \mathrm{p}$.

50. MCGEE, $Z_{A C H}$ A Study in the Play Life of Some South Carolina Children. Ped. Sem., 1900, vol. 7, pp. 459-79.

51. MaXweli, W. H. Twelfth Annual Report of the City Superintendent, City of New York, I9ro, 656 p.

52. Mayer, August. Ueber Einzel-und Gesamtleistung des Schulkindes. Sammlung von Abhandlungen zur Psychologischen Pädagogik, I. 4. Leipzig, 1904.

53. Meumann, E. Haus-und Schularbeit. Die Deutsche Schule, June, 1904, pp. 337-59.

54. MEYeR, B. F. Fraternal Beneficiary Societies. Am. Jour. Sociol., I 901, vol. 6, pp. 646-6I.

55. Morrison, G. B. Report of Committee on Fraternities. Proc. of $N$.E. A., 1905. pp. 445-51.

56. Mumford, EBEN. The Origins of Leadership. Univ. Press, Chicago, I909. $87 \mathrm{p}$.

57. N. Y. State Dept. of Labor Bulletin, I9ro, vol. I2, no. 45

58. O'SheA, M. V. Social Development and Education. Houghton, Boston, r909, 56r p.

59. PEREZ, BERNARD. The First Three Years of Childhood. Bardeen, Syracuse, I 889, 294. p.

6o. Preyer, J. A. Mental Development in the Child. Appleton, N. Y., 1893, $170 \mathrm{p}$.

61. PUFFER, J. A. Boys' Gangs. Ped. Sem., 1905. vol. 12, pp. 175-213.

62. RATZELHOFER, G. Die Sociologische Erkenntniss. Brockhaus, Leipzig, 1898, 372 p.

63. Riвот, Tн. The Psychology of the Emotions. Scribner's, London, r898, $455 \mathrm{p}$.

64. Rirs, J. A. How the Other Half Lives. Scribner's, N. Y., r890, 304 p.

65. Ross, E. A. Social Control. Macmillan, N. Y., 1904, 463 p.

66. ScorT, J. H. The Social Instinct and its Development in Boy Life. Association Sem., 1905, vol. 13, 46 p. 
67. Sheldon, H. D. Institutional Activities of American Children. Am. Jour. Psych., 1898, vol. 9, pp. 428-48.

68. _ - The History and Pedagogy of American Student Societies. Appleton, N. Y., 1901, 366 p.

69. Simmer, GeOrg. The Persistence of Groups. Am. Jour. Sociol., 1898, vol. 3, pp. 662-98; pp. 829-36; vol. 4, pp. 35-50.

70. - The Sociology of Secrecy. Am. Jour. Sociol., 1906, vol. II, pp. 44I-98.

71. Suosson, E. E. Great American Universities. Macmillan, N. Y., $1910,528 \mathrm{p}$.

72. SchmidT, FrIEDRICH. Experimentelle Untersuchungen über die Hausaufgaben des Schulkindes. I, 3. Leipzig, 1904, 120 p.

73. SmrTh, S. R. Report of the Committee on the Influence of Fraternities in Secondary Schools, School Rev., 1905, vol. 13, pp. 1-Io.

74. Spectator, The. The Outlook, 1907, vol. 87, pp. 769-70.

75. Stanton, E. C., Anthony, S. B., and GaGe, M. J. History of Woman Suffrage. Mann, Rochester, I 889-1902, 4 vols.

76. Stevens, A. C. The Cyclopedia of Fraternities. Treat, N. Y., 1907, $444 \mathrm{p}$.

77. Sudermann, Hermann. Der Sturmgeselle Sokrates. Cotta, Stuttgart, $1903,170 \mathrm{p}$.

78. Sully, JAmES. Studies of Childhood. Appleton, N. Y., I 896, 527 p.

79. Sutherland, $A$. The Origin and Growth of the Moral Instinct. Longmans, London, 1898,2 vols.

80. TARDE, GABRIEL. The Laws of Imitation. Holt, N. Y., 1903, 404 p,

8I. Titchener, E. B. A Textbook of Psychology. Macmillan, N. Y.. I9IO, $558 \mathrm{p}$.

82. Tolstor, L. War and Peace. Complete Works. Crowell, N. Y., t898, 6 vols.

83. TRIPLETT, N. The Dynamogenic Factors in Pace-Making and Competition. Am. Jour. Psych., 1898, vol. 9, pp. 507-33.

84. VARENDonck, J. Les Sociétés D'Enfants. A questionnaire. Arch. de Psychologie, 1910, vol. 9, pp. 134-38.

85. WARNER, C. D. Being a Boy. Houghton, Boston, r889. 244 p.

86. Whrтсомв, C. T. C. Report on Organizations among High School Students. 69th Mass. Report of Education, 1904-05, pp. 180-98.

87. Woods, Robert. The City Wilderness. Houghton, Boston, 1909, $319 \mathrm{p}$.

88. World Almanac and Encyclopedia. Press Pub. Co., N. Y., I9 I I, 816 p.

89. Y. M. C. A. of Mass. and R. I. Report of the Committee on Fraternity and Social Life in High Schools. MS., I909, 25 p. 



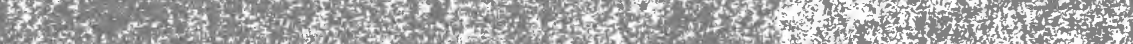

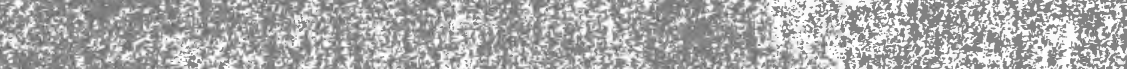

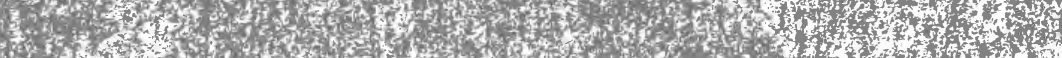
35. 5 (3)

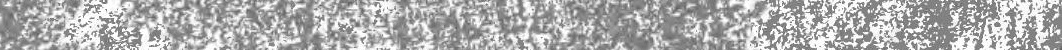

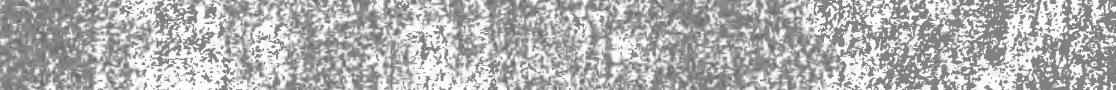

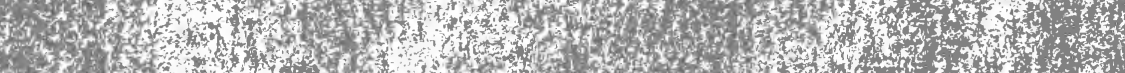

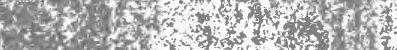
8. 15 at

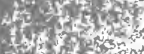

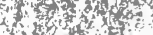

\section{ato}

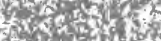

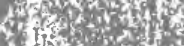

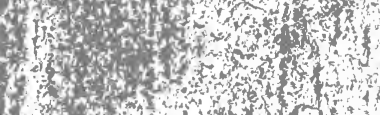

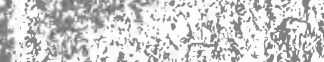

I. 30 , w

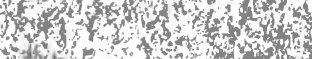

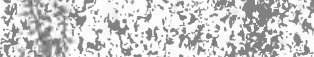

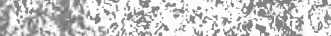

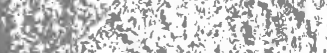

3)

$x_{0}, 0$

tis.

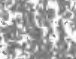

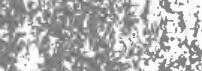

an $x^{2}+4^{2}$

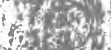

fes $5 x+1$

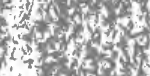

if 10

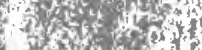

30 o

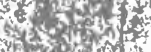

, ens

is

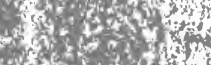

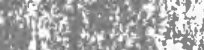

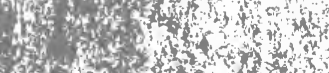

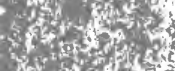

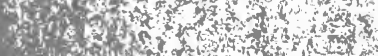

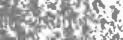

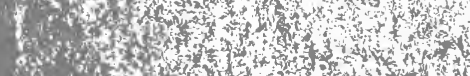

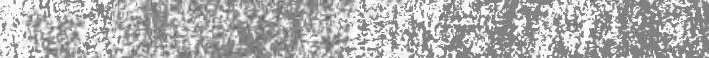

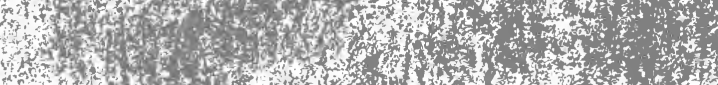
1. 3 (3)

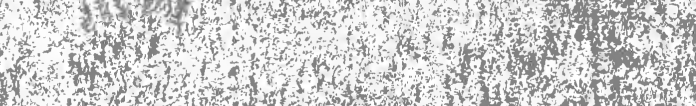

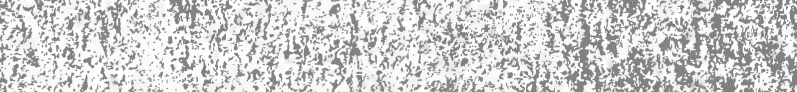

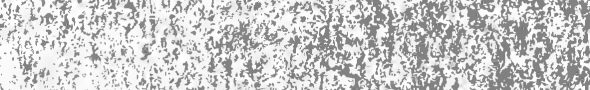

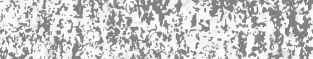
W.

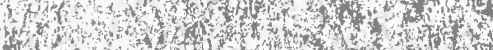
4.

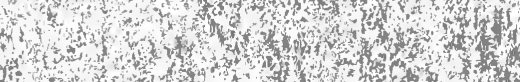
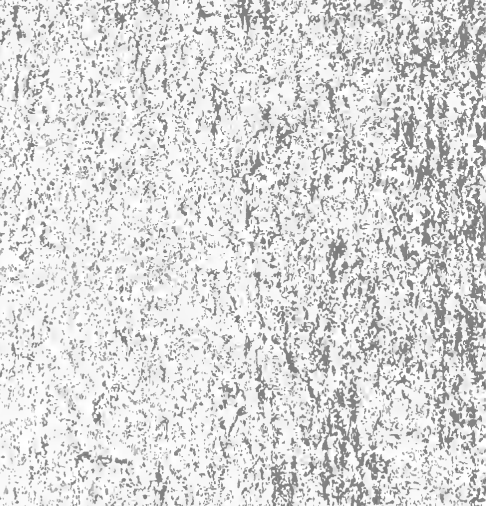

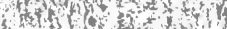

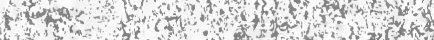

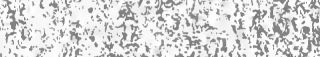
(1)

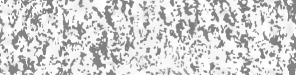

W

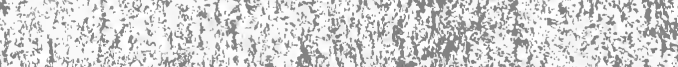
1.

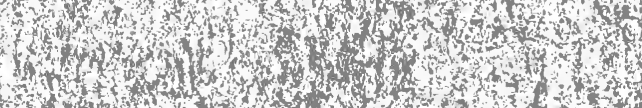
(1) 4.

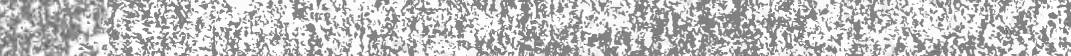

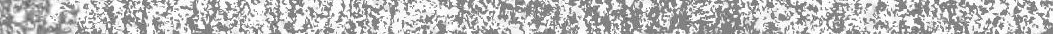




\section{TURN CIRCULATION DEPARTMENT 202 Main Library}

\section{AN PERIOD 1 HOME USE}

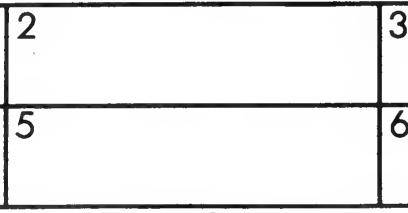

ALL BOOKS MAY BE RECALLED AFTER 7 DAYS

1 -month loans may be renewed by calling $642-3405$ ionth loans may be recharged by bringing books to Circulation Desk Renewals and recharges may be made 4 days prior to due date

DUE AS STAMPED BELOW

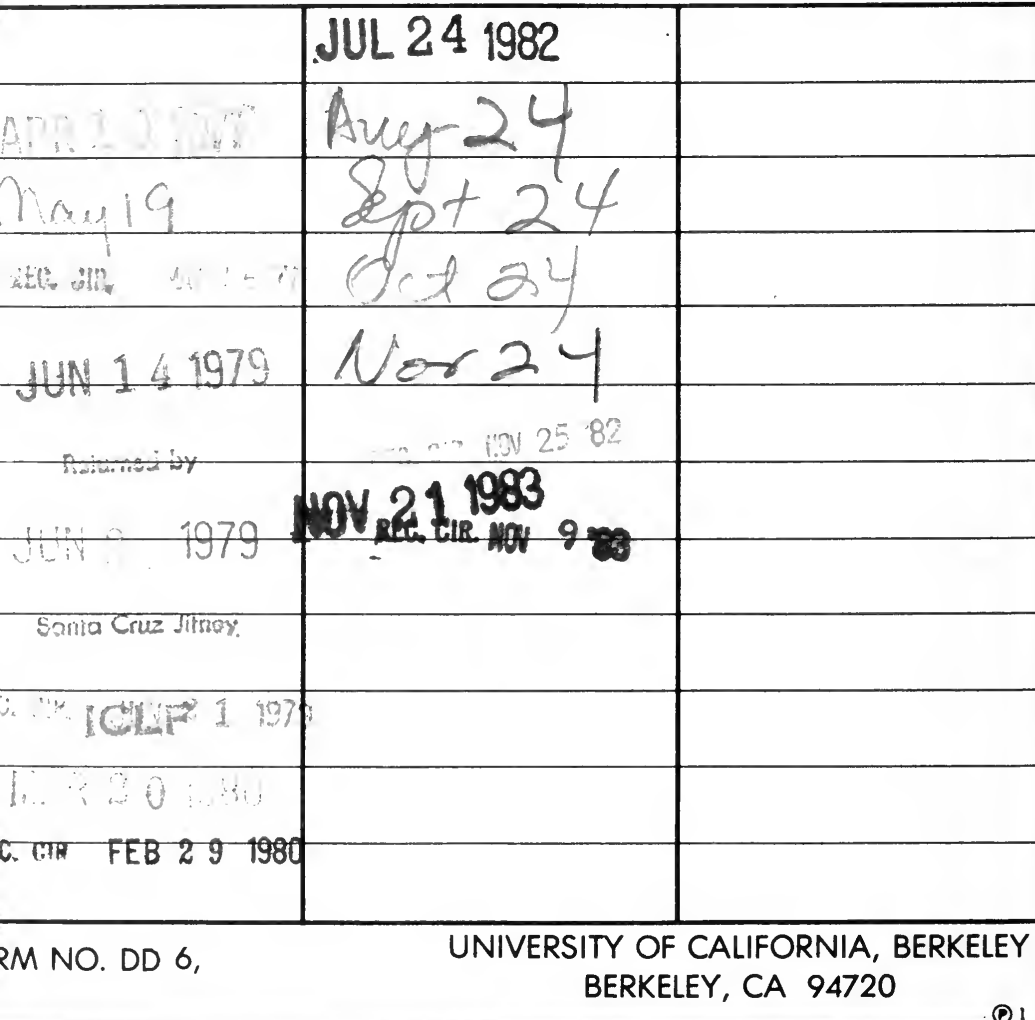


